\title{
IDENTIFICAÇÃO MOLECULAR DE FITOPLASMA ASSOCIADO AO ENFEZAMENTO DO TOMATEIRO (Lycopersicon esculentum) E DA BERINJELA (Solanum melongena)
}

\section{ANA PAULA DE OLIVEIRA AMARAL MELLO}

Dissertação apresentada à Escola Superior de Agricultura "Luiz de Queiroz", Universidade de São Paulo, para obtenção do título de Mestre em Agronomia, Área de Concentração: Fitopatologia.

\author{
PIRACICABA \\ Estado de São Paulo - Brasil \\ Dezembro - 2003
}




\title{
IDENTIFICAÇÃO MOLECULAR DE FITOPLASMA ASSOCIADO AO ENFEZAMENTO DO TOMATEIRO (Lycopersicon esculentum) E DA BERINJELA (Solanum melongena)
}

\author{
ANA PAULA DE OLIVEIRA AMARAL MELLO \\ Engenheira Agrônoma
}

Orientador: Prof. Dr. IVAN PAULO BEDENDO

Dissertação apresentada à Escola Superior de Agricultura "Luiz de Queiroz", Universidade de São Paulo, para obtenção do título de Mestre em Agronomia, Área de Concentração: Fitopatologia.

\author{
PIRACICABA \\ Estado de São Paulo - Brasil \\ Dezembro - 2003
}


Dados Internacionais de Catalogação na Publicação (CIP) DIVISÃO DE BIBLIOTECA E DOCUMENTAÇÃO - ESALQ/ USP

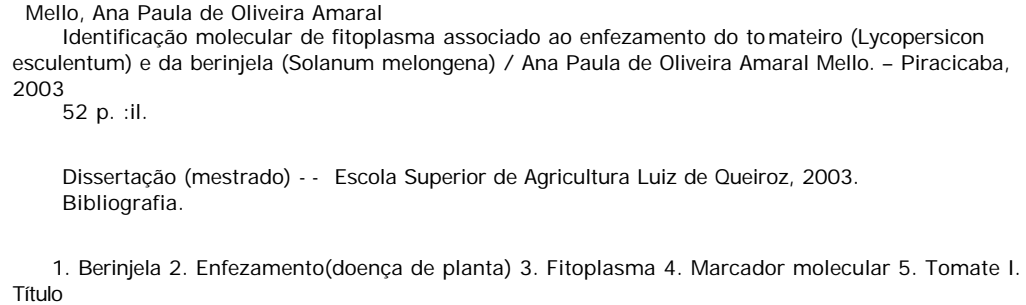

CDD 635.642

\section{'Permitida a cópia total ou parcial deste documento, desde que citada a fonte - $\mathrm{O}$ autor"}


Aos meus pais, Toninho e Maria Irene, pelo amor e carinho de sempre, que permitiram tornar-me a pessoa que sou, com amor, DEDICO.

"A coisa mais bela que o homem pode experimentar é o mistério. É essa emoção fundamental que está na raiz de toda ciência e toda arte"

(Albert Einstein)

\author{
À Tia la, aos meus irmãos \\ Juliana, Luís Gustavo e Ana Raquel, \\ por estarem sempre por perto, com \\ amor, OFEREÇO.
}




\section{AGRADECIMENTOS}

A Deus, por me segurar nos braços em todos os momentos, sobretudo nas horas de aflição, pela graça de mais uma etapa vencida e por ter me dado a família que tenho;

Ao Prof. Dr. Ivan Paulo Bedendo, pela orientação desta dissertação, pelo incentivo, confiança, paciência e pela enorme contribuição em minha formação como pesquisadora;

Ao Prof. Dr. Luis Eduardo Aranha Camargo, pela concessão de uso do Laboratório de Genética Molecular do Setor de Fitopatologia da ESALQ/USP e pela gentileza de sempre, colaborando para a realização deste trabalho;

Ao Prof. Dr. Nelson Massola Júnior por toda parte de microscopia eletrônica e pelas fotos perfeitas que complementaram nossos resultados;

Ao Prof. Dr. Elliot W. Kitajima, por ter cedido uma foto de microscopia, e dessa maneira colaborado com nossos resultados finais;

Ao Prof. Dr. Alfredo S. Urashima, pelas correções em meu Summary e contribuição em minha escolha pela área de fitopatologia;

A todos do Laboratório de genética Molecular, que foram extremamente gentis comigo, especialmente à Daniela Truffi, Flávia, Maria Cristina e Osmar, por toda ajuda que me deram nas etapas do sequenciamento;

A Dra Cláudia Vitorello por ter sido sempre tão gentil quanto às minhas dúvidas com as ferramentas da genética molecular;

A todos os professores e funcionários do Setor de Fitopatologia da ESALQ/USP pelos conhecimentos transmitidos, pelo sentimento de amizade e por toda contribuição neste trabalho; 
Ao Dr. Ricardo Gioria por toda colaboração e valiosa contribuição;

Ao Conselho Nacional de Desenvolvimento Científico e Tecnológico (CNPq), pela concessão da bolsa de estudo durante o desenvolvimento desta dissertação;

Aos amigos Adriana Z. Kronka e Luiz Fernando C. Ribeiro, pelas boas risadas que demos juntos, pelos bons e maus momentos compartilhados;

Aos amigos do Laboratório de Fitopatologia Molecular, Carol, Jorge, Mariana, Raquel e Ricardo;

A todos os amigos dos demais laboratórios do Setor de Fitopatologia da ESALQ/USP;

À Nilceli Fernandes pelo exemplo de determinação e garra, pela grande amizade e pelas sugestões a esse trabalho;

A todo(a)s o(a)s grandes amigo(a)s que eu "abandonei" durante a realização dessa dissertação, mas que souberam entender minha ausência;

A todos que de uma forma ou de outra contribuíram para a realização deste trabalho;

Agradecimento especial à querida amiga Patrícia Cia por toda força, amizade, paciência, incentivo, companheirismo e por todas as sugestões enriquecedoras a este trabalho;

Finalmente, agradeço à minha família em especial a meus pais, minha tia, meu irmão e minhas irmãs por existirem em minha vida, por toda a paciência, incentivo, amizade, compreensão e amor;

Obrigada. 


\section{SUMÁRIO}

Página

LISTA DE FIGURAS.................................................................... viii

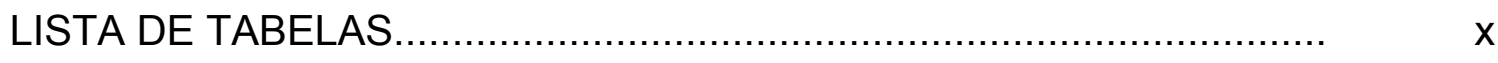

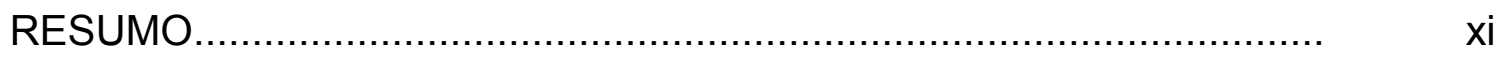

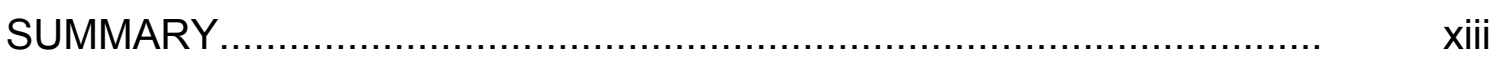

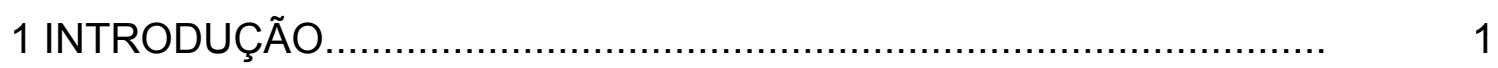

2 REVISÃO DE LITERATURA.....................................................

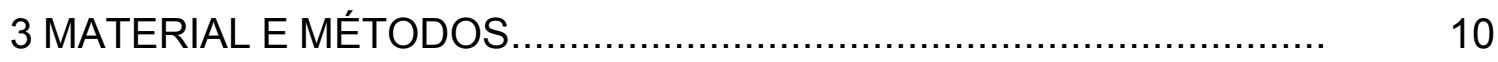

3.1 Amostras de plantas de tomate e berinjela................................... 10

3.2 Deteç̧ão de fitoplasma por PCR .................................................. 10

3.2.1 Extração de DNA total das amostras.............................................. 10

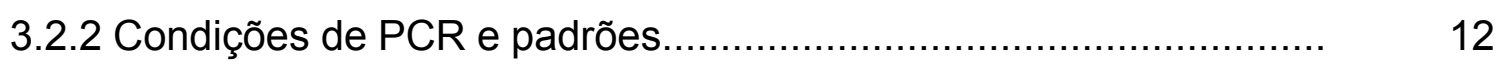

3.3 Identificação de fitoplasma por PCR ……….................................. 13

3.3.1 Oligonucleotídeos específicos para classificação em grupos.......... 13

3.4 Oligonucleotídeos..................................................................... 13

3.5 Eletroforese em gel de agarose e marcador molecular..................... 14

3.6 Microscopia eletrônica de transmissão............................................ 14

3.7 Teste de transmissão por enxertia................................................ 15

3.8. Identificação de fitoplasma por análise de RFLP............................. 15

3.8.1 Caracterização do fitoplasma.................................................... 15

3.8.2 Enzimas de restrição......................................................... 15

3.8.3 Eletroforese em gel de poliacrilamida, marcador molecular e modo de análise dos resultados...................................................... 16 


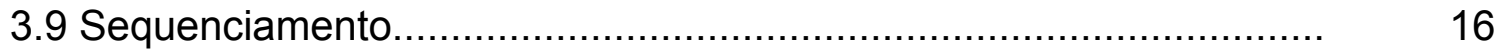

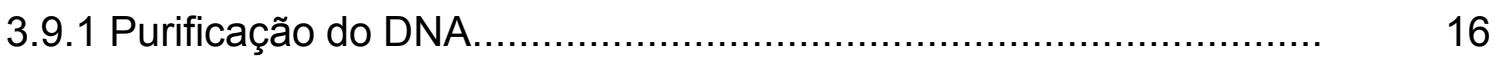

3.9.2 Ligação ao vetor plasmidial.......................................................... 17

3.9.3 Transformação de células competentes por choque térmico e

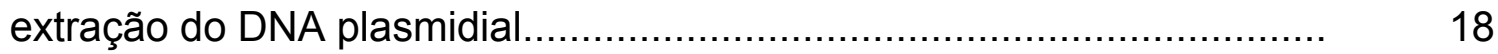

3.9.4 Reação de PCR para sequenciamento........................................ 19

3.9.5 Seqüência de nucleotídeos e análise ............................................ 19

4 RESULTADOS E DISCUSSÃO................................................ 21

4.1 Sintomatologia e teste de transmissão por enxertia............................ 21

4.2 Detecção através de duplo PCR ................................................. 25

4.3 Identificação do fitoplasma através de PCR ..................................... 25

4.4 Microscopia eletrônica de transmissão.......................................... 26

4.5 Identificação através da análise por RFLP.................................... 28

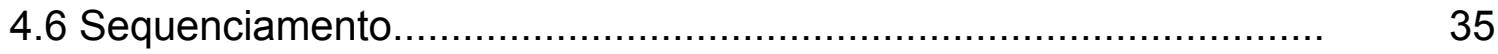

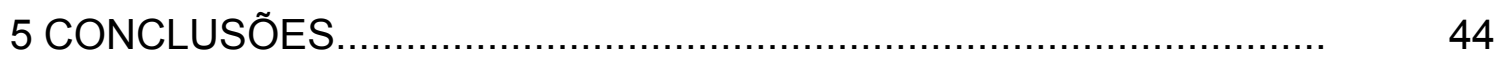

REFERÊNCIAS BIBLIOGRÁFICAS............................................ 45 


\section{LISTA DE FIGURAS}

Página

1 Posição do par de primer F2N/R2 no gene 16S rDNA....................... 13

2 Sintomas de enfezamento e clorose foliar acentuada em tomateiro, observados no campo............................................................ 22

3 Redução no tamanho de frutos em tomateiro................................... 22

4 Sintomas de enfezamento generalizado, observado no campo, em planta de berinjela ........................................................... 23

5 Redução no tamanho de frutos, folha e flores em berinjela................ 23

6 Planta de berinjela enxertada experimentalmente exibindo sintomas típicos de doenças de natureza fitoplasmática.................................. 24

7 Deformação do cálice em berinjela enxertada experimentalmente.... 24

$8 \mathrm{Gel}$ de agarose (1\%) para grupo específico.................................... 26

9 Microscopia eletrônica mostrando elemento de vaso crivado do floema de berinjela infectada........................

10 Presença de corpúsculos pleomórficos no lúmen de elemento de vaso crivado no floema de tomateiro infectado..............................

11 Produtos de digestão enzimática com as endonucleases Alul, Msel, Hpall, Kpnl, Rsal e Kpnl . Análise dos produtos de duplo PCR conduzido com os pares de oligonucleotídeos $\mathrm{R} 16 \mathrm{mF} 2 / \mathrm{mR} 1$ e R16F2N/R2 para as amostras EB01 e EB02 ..............................

12 Produtos de digestão enzimática com as endonucleases Alul, Hpall, Msel, Rsal, Mbol. Kpnl e Hhal. Análise dos produtos de duplo PCR conduzido com os pares de oligonucleotídeos 
$\mathrm{R} 16 \mathrm{mF} 2 / \mathrm{mR} 1$ e R16F2N/R2, para a amostra ET02 ......................

13 Produtos de digestão enzimática com a endonuclease Hhal. Análise dos produtos de duplo PCR conduzido com os pares de oligonucleotídeos R16mF2/mR1 e R16F2N/R2, para as amostras

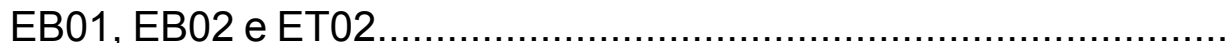

14 Árvore filogenética da seqüência do $16 S$ rDNA dos fragmentos clonados obtidos a partir das amostras EB01, EB02 e ET02, construída pelo método "Neighbor-Joining", do programa CLUSTALW

15 A - Análise dos mapas de restrição gerados das seqüências do 165 rDNA dos fragmentos clonados dos fitoplasmas provenientes das amostras EB01 e EB02 .................................

15 B - Análise dos mapas de restrição gerados das seqüências do 16S rDNA dos fragmentos clonados dos fitoplasmas provenientes das amostras EB02 e ET02 .................................. 


\section{LISTA DE TABELAS}

Página

1 Comparação dos padrões de perfil eletroforético dos isolados das amostras EB01, EB02, ET02 com outros fitoplasmas afiliados ao grupo 16Srlll obtidos através de análise de RFLP..........................

2 Posições dos polimorfismos nas seqüências do 16S rDNA do

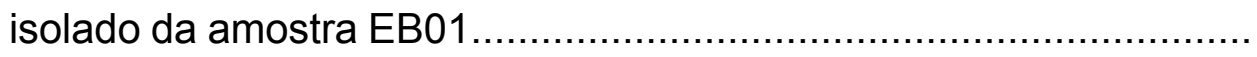

3 Posições dos polimorfismos nas seqüências do 165 rDNA do isolado da amostra ET02 ........................................................... $\quad 36$

4 Posições dos polimorfismos nas seqüências do 165 rDNA do isolado da amostra EB02 ......................................................... 36

5 Fitoplasmas do grupo 16Srlll, números de acesso no "GenBank" e referências usadas nesse trabalho.......................................... 


\title{
IDENTIFICAÇÃO MOLECULAR DE FITOPLASMA ASSOCIADO AO ENFEZAMENTO DO TOMATEIRO (Lycopersicon esculentum) E DA BERINJELA (Solanum melongena)
}

\author{
Autora: ANA PAULA DE OLIVEIRA AMARAL MELLO \\ Orientador: Prof. Dr. IVAN PAULO BEDENDO
}

\section{RESUMO}

Fitoplasmas, procariotos sem parede celular e habitantes de floema, têm causado danos consideráveis em diversas culturas comercialmente importantes. A associação desses fitopatógenos com várias doenças que ocorrem em espécies hortícolas têm sido comumente registradas tanto no território brasileiro como em outras regiões do mundo. Em áreas de plantio comercial, na região de Piracicaba-SP e Bragança Paulista-SP, plantas de tomate e berinjela apresentando porte reduzido, clorose foliar acentuada, produção exagerada de pequenos ramos, desenvolvimento anormal do cálice, encurtamento de entre-nós, redução no tamanho de folhas, flores e frutos, que podem ser traduzidos em sintomas de enfezamento, foram observadas evidenciando infecção por fitoplasma. Através da técnica de duplo PCR utilizando os oligonucleotídeos universais R16 mF1/mR2 e R16 F2n/R2, 
fragmentos de DNA de 1,2 Kb foram amplificados de amostras sintomáticas, demonstrando a presença de fitoplasma nos tecidos das plantas. Nenhum fragmento foi detectado em plantas sadias. O exame de tecidos do floema de plantas sintomáticas, submetidos ao microscópio eletrônico de transmissão, revelou a presença de corpúsculos pleomórficos no interior dos vasos, corroborando com os resultados da detecção através de PCR. O uso de oligonucleotídeos específicos para identificação demonstrou a ocorrência de fitoplasmas afiliados ao grupo 16SrllI, tanto em tomate quanto em berinjela. Análises de RFLP, usando as enzimas de restrição Alul, Msel, Hpall, Kpnl, Rsal, Hhal e Mbol, confirmaram a ocorrência de fitoplasmas do referido grupo em ambas as espécies vegetais. Para confirmar os resultados de RFLP, os fragmentos de DNA de 1,2 Kb dos fitoplasmas presentes em tomate e berinjela, amplificados com o par de iniciadores R16 F2n/R2, foram clonados em Escherichia coli para a determinação de suas seqüências de nucleotídeos. Os fragmentos clonados sequenciados foram comparados, por homologia de nucleotídeos, entre si e com isolados cujas seqüências já haviam sido depositadas no "GenBank". O resultado do sequenciamento revelou heterogeneidade das seqüências do gene 16S rDNA ocorrendo em alguns isolados, demonstrando e confirmando a variabilidade genética de organismos do grupo 16Srlll presentes no Brasil. 


\title{
MOLECULAR IDENTIFICATION OF PHYTOPLASMA ASSOCIATED TO TOMATO (Lycopersicon esculentum) AND EGGPLANT (Solanum melongena) STUNTING
}

\author{
Author: ANA PAULA DE OLIVEIRA AMARAL MELLO \\ Adviser: Prof. Dr. IVAN PAULO BEDENDO
}

\section{SUMMARY}

Phytoplasmas are cell wall-less prokaryotes and phloeminhabitants. They caused considerable damages in some commercially important crops in the Brazilian territory and others regions of the world. It has been observed in the region of Piracicaba and Bragança Paulista, São Paulo State, commercial fields of eggplant and tomate showing reduced size, extensive chlorosis, proliferation of axillary buds, abnormal development of calyx, internode shortening and small leaves, flowers and fruits. These symptoms can be translated by stunting, making clear the phytoplasma infection. Presence of phytophasm was confirmed by nested PCR assay with the universal primer R16 F2N/R2 where DNA fragments of $1.2 \mathrm{~kb}$ were amplified from symptomatic samples. No fragments was observed in healthy plants. Analysis of symptomatic plant's phloem tissue when submitted to electron microscope of transmission, disclosed the presence of pleomorphic bodies 
inside the tissues, corroborating with the results of detection by PCR assay. The use of specific primers for groups demonstrated the phytoplasmas occurrence associated to the $16 \mathrm{Srlll}$ group, in both tomato and eggplant. RFLP analyses using Alul, Msel, Hpall, Kpnl, Rsal, Hhal and Mbol restriction enzymes confirmed the occurrence of phytoplasmas on 16Srll group in both plant species with typical stunting symptoms. The products of $1.2 \mathrm{~kb}$ of tomato and eggplant isolates amplified with the pair of primers R16 F2n/R2, were cloned in Escherichia coli to determine nucleotides sequence and to confirm the RFLP results. The nucleotide sequences were compared by homology and with isolates whose sequence have been already deposited in the "GenBank". The results revealed 16S rRNA sequence heterogeneity occurring in some isolates showing the genetic variability of group 16Srlll phytoplasma in Brazil. 


\section{INTRODUÇÃO}

Fitoplasmas são procariotos, membros da classe Mollicutes, habitantes de vasos do floema e naturalmente transmitidos por cigarrinhas. Apesar de inúmeras tentativas, seu isolamento para meio de cultura ainda não foi possível. Isto se constitui no maior obstáculo para o desenvolvimento de pesquisas que visam estudar as doenças associadas a estes microrganismos.

A patogenicidade destes agentes tem sido demonstrada através de sua detecção na planta, transmissão de planta doente para planta sadia e remissão de sintomas através de tratamento com o antibiótico tetraciclina. A diagnose das doenças associadas aos fitoplasmas é dificultada devido à impossibilidade de isolamento dos mesmos a partir do tecido doente, à similaridade com sintomas provocados por vírus e à ocorrência de plantas portadoras de infecção latente. Dessa maneira, a deteç̧ão de fitoplasma em plantas e insetos vetores é um fator de grande importância para a diagnose de doenças e estudos epidemiológicos.

A identificação destes microrganismos é importante, pois permite demonstrar a presença de diferentes fitoplasmas numa mesma espécie vegetal ou relacionar fitoplasmas similares que ocorrem em espécies vegetais diferentes. Fitoplasmas similares podem causar diferentes sintomas em hospedeiros vegetais distintos, enquanto fitoplasmas distintos podem ser veiculados pela mesma espécie de vetor e provocar sintomas diferentes numa mesma espécie botânica. Este tipo de informação pode contribuir para um maior entendimento sobre a epidemiologia da doença, visando a adoção de medidas de controle mais eficientes. A necessidade de se determinar métodos 
práticos para o controle de doenças tem sido o principal objetivo das pesquisas que vêm sendo feitas com fitoplasmas.

Nesse contexto, a biotecnologia tem sido uma importante ferramenta para a detecção e identificação molecular de fitoplasmas e tem contribuído de modo prático e confiável para a diagnose de inúmeras doenças associadas a esses fitopatógenos.

Fitoplasmas ocorrem em diversas espécies vegetais cultivadas, daninhas ou silvestres. Dentre as cultivadas, estão associados a diversas doenças de hortaliças, frutíferas, cereais e ornamentais.

Durante o ano de 2002 plantas de tomate, apresentando porte reduzido, clorose foliar acentuada, produção exagerada de pequenos ramos, desenvolvimento anormal do cálice, encurtamento de entre-nós, folhas, flores e frutos de tamanho reduzido, sintomas típicos de enfezamento, foram coletadas em Bragança Paulista-SP, suspeitas de estarem infectadas por fitoplasma. Plantas de berinjela, proveniente de Bragança Paulista-SP e Piracicaba-SP, apresentando sintomas semelhantes àqueles constatados em tomateiro também foram alvo de pesquisa, buscando relacionar os sintomas com a presença de fitoplasmas.

Devido à importância econômica das culturas de tomate e berinjela, no Estado de São Paulo, a ocorrência de plantas com sintomas de enfezamento despertou a atenção, pois o problema já havia sido relatado em outros países, resultando em sérios danos às culturas. Assim, o presente trabalho teve por objetivos: detectar e identificar, com o uso de oligonucleotídeos específicos, fitoplasma(s) associado(s) ao enfezamento em plantas de tomate e berinjela, através da técnica de duplo PCR; caracterizá-lo(s) molecularmente, pela técnica de RFLP e sequenciar o(s) fragmento(s) genômico(s) do(s) fitoplasma(s) detectado(s), analisando a homologia de sua(s) seqüência(s). 


\section{REVISÃO DE LITERATURA}

No final da década de 60, pesquisadores japoneses demonstraram que as doenças de plantas, conhecidas como "aster yellows" (amarelos), estavam associadas a organismos unicelulares, do tipo micoplasma (MLOs) (Doi et al., 1967). Três décadas depois foi proposto o termo fitoplasma para designar os MLOs associados às doenças em plantas (Sears \& Kirkpatrick, 1994).

De acordo com Davis \& Lee (1991), a principal característica das plantas infectadas por fitoplasmas é a ocorrência de desequilíbrio no balanço hormonal das mesmas. Os danos provocados pela presença do patógeno podem ser variáveis, dependendo do genótipo da planta suscetível, da estirpe do patógeno e do ambiente, podendo em alguns casos ter um efeito devastador para a cultura (Davis, 1995).

No Brasil, uma ampla diversidade de gêneros e espécies vegetais são afetadas por doenças associadas aos fitoplasmas (Kitajima, 1994). Em geral, plantas infectadas podem exibir sintomas de clorose generalizada das folhas, desenvolvimento de brotos extra-numerários, clareamento ou avermelhamento das nervuras, enfezamento, deformação dos órgãos florais, esterilidade, filodia, virescência, entre outros (Kitajima \& Costa, 1970; Kirkpatrick, 1992; Davis, 1995). Há registros no país de diversas doenças associadas a este tipo de fitopatógeno, entre elas, o superbrotamento do feijoeiro, da soja, do maracujazeiro e da mandioca, o enfezamento vermelho do milho, o irizado do chuchuzeiro, o cálice gigante do tomateiro e o declínio do 
caquizeiro (Kitajima, 1995), algumas das quais têm trazido sérios prejuízos para os produtores.

A transmissão dos fitoplasmas pode ocorrer natural ou experimentalmente através de insetos vetores e Cuscuta sp. e, de forma ocasional ou experimental, por enxertia (Davis, 1995; Goodwin et al., 1999). De acordo com Murral et al. (1996), de maneira geral, os fitoplasmas causadores de enfezamento são transmitidos por cigarrinhas e devido à ocorrência irregular da doença ao longo do tempo, o controle torna-se problemático. Segundo estes autores, em alguns anos a incidência da doença é baixa, apesar da presença abundante de cigarrinhas no campo e, em outros, a incidência é tão alta que campos inteiros são perdidos. Relato semelhante foi feito por Khadhair et al. (2002), acrescentando ainda que a interação entre fitoplasma, inseto vetor e planta hospedeira, apresenta várias implicações, como por exemplo, a planta infectada servir de fonte de inóculo, contribuindo para o aumento da doença no campo.

$\mathrm{Na}$ impossibilidade de cultivar o fitopatógeno em meio de cultura, as pesquisas sobre o assunto têm sido feitas através de bioensaios com insetos vetores (Hoy et al., 1992) e a manutenção dos isolados através de enxertia (Boiteux et al., 1994). A transmissão por enxertia ocorre pelo contato direto entre os tecidos do floema da planta infectada e os da planta sadia, os quais devem ser compatíveis para que haja união, permitindo a passagem do patógeno do tecido doente para o sadio. De acordo com Davis et al. (1991), além das hospedeiras naturais, a manutenção dos isolados pode ser feita em plantas de vinca (Catharanthus roseus) devido ao seu rápido crescimento, facilidade de transmissão através de enxertia, insetos vetores e cuscuta, bem como por apresentarem sintomas diferentes ao serem inoculadas com fitoplasmas de grupos distintos.

Desde os trabalhos pioneiros de Doi et al. (1967), a diagnose de numerosas enfermidades associadas a fitoplasmas tem sido baseada essencialmente na detecção de corpúsculos pleomórficos, presentes nos vasos 
crivados das plantas afetadas, através de microscopia eletrônica de transmissão. No Brasil, muitos dos trabalhos que associaram plantas exibindo sintomas típicos aos fitoplasmas foram feitos através dessa técnica (Kitajima \& Costa, 1970; Kitajima, 1994). No entanto, seu uso rotineiro nem sempre é viável devido ao alto custo do equipamento, à necessidade de pessoas altamente treinadas, além de não contribuir para a identificação do fitoplasma, devido à impossibilidade de distinção morfológica entre esses fitopatógenos (Barros, 1997).

O advento da biotecnologia tornou possível o reconhecimento da seqüência do $16 S$ rDNA de fitoplasmas (Lim \& Sears, 1989; Kirkpatrick et al., 1988), permitindo sintetizar oligonucleotídeos universais para amplificação de suas seqüências específicas através da técnica de "Polymerase Chain Reaction" (PCR). Esta técnica tem sido utilizada, predominantemente, para a detecção do patógeno, embora a construção de oligonucleotídeos específicos para identificação tenha possibilitado a classificação de fitoplasmas em grupos bem definidos (Firrao et al., 1994; Lee et al., 1995; Harrison et al., 1996, Martin et al., 2000). A sensibilidade da técnica, principalmente de duplo PCR, tem permitido a detecção de fitoplasmas em plantas e insetos vetores, mesmo quando o patógeno ocorre em baixas concentrações (Schaff et al., 1992; Henson \& French, 1993; Marcone et al., 1996; Green et al., 1999).

A técnica de "Restriction Fragment Length Polymorphisms" (RFLP), que consiste em analisar os padrões gerados por enzimas de restrição, tem sido adotada internacionalmente para fins de identificação e classificação de fitoplasmas (Lee et al., 1998; Marcone et al., 2000; Siddique et al., 2001). Segundo Alma et al. (1996), a maior vantagem dessa técnica é a possibilidade de detectar infecções mistas ocorrendo numa mesma planta. Kitajima (1994) afirma ser comum esse tipo de infecção. Essa informação pode ser bastante importante em estudos epidemiológicos e na adoção de medidas de controle eficientes. 
O sequenciamento da região $16 \mathrm{~S}$ rDNA também tem sido bastante utilizado para fins de classificação de fitoplasmas, através da homologia de suas seqüências nucleotídicas e análise filogenética (Gundersen et al., 1994; Montano et al., 2001; Siddique et al., 2001; Khan et al., 2002). Recentemente, pesquisas envolvendo o sequenciamento do genoma de fitoplasmas começaram a ser desenvolvidas. Esses estudos têm permitido uma maior compreensão dos mecanismos de patogenicidade do organismo, sua evolução, expressão de genes de resistência da planta em resposta às infecções, mecanismos de transmissão por insetos vetores, além de permitir o desenvolvimento de métodos mais efetivos para o controle das doenças no campo (Lee et al., 2000).

Tomate e berinjela são hortaliças consumidas "in natura" e contêm substâncias capazes de combater os radicais livres inibindo hormônios causadores de doenças degenerativas. Nos países onde o novo conceito de alimentação saudável e segurança alimentar estão consolidados, essas hortaliças detêm boa parte do mercado. No Brasil, ocupam uma posição de destaque econômico, possibilitando boa rentabilidade aos produtores, devido à alta produtividade e tendência de aumento de demanda (FNP Consultoria \& Comércio, 2000).

Doenças de etiologia fúngica, bacteriana e viral têm papel relevante sobre o rendimento destas culturas. Apesar dos enfezamentos em tomate e berinjela serem conhecidos fora do país, no território brasileiro existem poucas informações sobre a ocorrência destas doenças. Na verdade, os sintomas provocados por estes fitopatógenos podem ser confundidos com sintomas causados por vírus e por desbalanços na nutrição mineral das plantas. Assim, os enfezamentos podem estar ocorrendo em diferentes áreas produtoras, podendo, no entanto, estar sendo confundidos com outras causas, pois doenças associadas aos fitoplasmas, de modo geral, ainda são pouco conhecidas por técnicos e produtores. 
As evidências da presença de fitoplasmas associados ao enfezamento em plantas de tomate e berinjela no estado de São Paulo são recentes. Em outros países, doenças associadas a fitoplasmas em tomate são conhecidas há algum tempo, embora seu agente causal tenha sido identificado somente na década de setenta (Granett \& Provvidenti, 1974; Dale \& Smith, 1975). De acordo com Samuel et al. (1933), alguns relatos de sintomas associados a fitoplasmas em tomate, na Europa, datam da década de trinta, porém eram atribuídos a vírus. O mesmo ocorreu quando Valenta et al. (1961) conduziram estudos sobre a doença "stolbur" no tomateiro, cujo fitoplasma, hoje se sabe, pertence ao grupo $16 \mathrm{SrXII}$, subgrupo XII-A. Outros relatos foram feitos na Índia (Varma, 1979), em Israel (Zimmermam-Gries \& Klein, 1978), e nos EUA (Coe \& Alstaff, 1947).

Segundo Shaw \& Kirkpatrick (1993), o cálice gigante do tomateiro, doença associada a um fitoplasma afiliado ao grupo $16 \mathrm{Srl}$, subgrupo I-A, foi descrito pela primeira vez na Austrália, somente na década de noventa e tem sido relatado em muitas outras áreas produtoras de tomate no mundo. Conduzindo estudos na região oriental da Jordânia, Anfoka et al. (2003) observaram sintomas de proliferação de ramos laterais, cálice gigante e virescência em tomateiro. Testes de PCR com oligonucleotídeos específicos para identificação indicaram que dois isolados não eram afiliados ao grupo $16 \mathrm{Srl}$ (grupo do "aster yellows"). Através da técnica de RFLP, os pesquisadores puderam classificá-los no grupo 16SrVI (grupo do "clover proliferation"), comprovando assim que fitoplasmas distintos podiam induzir sintomas semelhantes numa mesma espécie vegetal.

Na região central da Itália, Serrone et al. (2001), num levantamento realizado entre os anos de 1999 e 2000 em quatro áreas produtoras de tomate, observaram plantas exibindo sintomas de amarelecimento e avermelhamento das folhas, proliferação de ramos laterais, cálice gigante e virescência. Numa das áreas, a incidência atingiu níveis de $78 \%$ no ano de 1999 e de $82 \%$ no ano seguinte. Os fitoplasmas associados com a doença foram detectados e 
caracterizados pelas técnicas de PCR e RFLP, respectivamente, e foram classificados nos grupos 16Srl, 16Srlll, $16 \mathrm{SrV}$ e $16 \mathrm{SrXII}$, sendo este o primeiro relato da associação de fitoplasmas dos grupos $16 \mathrm{Srlll}$ e $16 \mathrm{SrV}$ com tomateiro nessa região.

No Irã, Salehi et al. (2000) transmitiram, através de enxertia e cuscuta, o fitoplasma associado ao superbrotamento do limão para berinjela e tomate, observando os mesmos sintomas presentes em limoeiro, tais como amarelecimento, redução no tamanho das folhas, encurtamento de entre-nós, virescência, filodia, superbrotamento, enfezamento, murcha e morte da planta.

Em Bangladesh, de acordo com Siddique et al. (2001), o primeiro estudo da doença "little leaf" em berinjela foi realizado no ano de $1999 \mathrm{em}$ plantas que exibiam amarelecimento e redução no tamanho das folhas, encurtamento de entre-nós, enfezamento e ausência de flores. Os resultados desse estudo confirmaram a associação dos sintomas com a presença de fitoplasmas nos tecidos de floema das plantas.

No final da década de 60, Kitajima \& Costa (1968) associaram pela primeira vez, no Brasil, organismos do tipo fitoplasma com o cálice gigante em tomateiro, através de microscopia eletrônica. Quase trinta anos depois, Boiteux \& Kitajima (1992) observaram, nos campos experimentais do CNPH/EMBRAPA, no Distrito Federal, plantas de berinjela exibindo sintomas típicos dos amarelos causados por fitoplasmas tais como, superbrotamento, clorose generalizada, folhas miúdas, porte ereto e cálice gigante. Exames de secções ultrafinas de tecido foliar demonstraram a presença de corpúsculos pleomórficos nos vasos crivados de plantas sintomáticas, demonstrando a associação de fitoplasmas com a doença, chamada por eles de superbrotamento. Os mesmos pesquisadores, em observações de campo realizadas na mesma área e no mesmo ano, descreveram, em outro trabalho, sintomas em plantas de berinjela caracterizados como superbrotamento, mudanças na estrutura floral, tais como cálice gigante, interrupção do desenvolvimento de anteras e ovário e virescência, comprovando através de enxertia e microscopia eletrônica a 
presença de fitoplasmas nessas plantas. Este se constituiu no primeiro relato de cálice gigante ocorrendo nessa cultura no país (Boiteux et al., 1994), porém nenhum estudo foi conduzido, na época, para classificação do patógeno detectado.

Barros (1997) caracterizou alguns isolados de fitoplasmas no Brasil, com base na análise dos padrões de restrição da seqüência 16S rDNA gerados pelas enzimas Hhal, Hpal, Hinfl e Rsal. Os resultados demonstraram que isolados encontrados em diferentes plantas de berinjela, com sintomas de cálice gigante e superbrotamento, provenientes do Distrito Federal e de São Paulo, respectivamente, provavelmente fossem membros do grupo 16Srlll-B. Para confirmar esses resultados, uma análise empregando um maior número de enzimas mostrou-se necessária.

Alguns anos mais tarde, Barros (2002), classificou os mesmos isolados como sendo pertencentes a um novo subgrupo dentro do grupo 16 Srlll, distinto de todos os subgrupos conhecidos até então, através de RFLP e homologia de nucleotídeos, revelando a presença de duas ou mais populações de moléculas de RNA ribossomal nos isolados estudados.

Frente ao exposto, nota-se claramente a relevância da detecção e caracterização de fitoplasma associado ao enfezamento em tomate e berinjela, duas culturas importantes economicamente para o país, para que se disponha de novos subsídios para o controle eficiente e economicamente viável desta doença. 


\section{MATERIAL E MÉTODOS}

\subsection{Amostras de plantas de tomate e berinjela}

Folhas de plantas sintomáticas e assintomáticas de tomate e berinjela foram amostradas em áreas de cultivo situadas na região de Bragança Paulista-SP e Piracicaba-SP, no ano de 2002. Os sintomas exibidos pelas plantas eram do tipo enfezamento, clorose acentuada, superbrotamento de ramos, encurtamento de entre-nós, folhas, flores e frutos de tamanho reduzido e deformação do cálice. As amostras de plantas de berinjela e tomate coletadas em Bragança Paulista receberam as indicações EB02 (Enfezamento da berinjela) e ET02 (Enfezamento do tomateiro) e as amostras de plantas de berinjela coletadas em Piracicaba, a indicação EB01.

\subsection{Detecção de fitoplasma por PCR}

\subsubsection{Extração de DNA total das amostras de tomate e berinjela}

A extração de DNA total foi feita a partir de material foliar, seguindo o método descrito por Lee et al. (1993). O DNA total extraído foi utilizado como modelo nas reações de PCR, visando a deteç̧ão de fitoplasmas.

Aproximadamente $2 \mathrm{~g}$ de material vegetal foram macerados em nitrogênio líquido e, em seguida, em um volume de $14 \mathrm{~mL}$ de tampão de extração I. O material macerado foi transferido para tubos de vidro de $30 \mathrm{~mL}$ e centrifugados em rotor SS-34 a $20000 \mathrm{~g}$ por 20 minutos a $4{ }^{\circ} \mathrm{C}$. O tampão foi descartado e o precipitado foi ressuspendido em $8 \mathrm{~mL}$ de tampão de extração II, $160 \mu \mathrm{L}$ de proteinase $\mathrm{K}$ e $880 \mu \mathrm{L}$ de sarcosyl 10\%. Após um período de 
incubação de 2 h a $55^{\circ} \mathrm{C}$, usando "banho maria", foi feita nova centrifugação a $7500 \mathrm{~g}$ por $10 \mathrm{~min}$. Ao sobrenadante foi adicionado $5,5 \mathrm{~mL}$ de isopropanol e os tubos foram mantidos durante uma noite a $-20{ }^{\circ} \mathrm{C}$. Após esse período, as amostras foram centrifugadas durante $15 \mathrm{~min}$ a $7500 \mathrm{~g}$, o precipitado foi ressuspendido em $3 \mathrm{~mL}$ de tampão $1 \mathrm{X} \mathrm{TE}, 75 \mu \mathrm{L}$ de SDS $20 \%$ e $60 \mu \mathrm{L}$ de proteinase K. O material foi incubado em "banho maria" por $1 \mathrm{~h}$ a temperatura de $37^{\circ} \mathrm{C}$ e, em seguida, foram adicionados $525 \mu \mathrm{L}$ de $\mathrm{NaCl} 5 \mathrm{M}$ e $420 \mu \mathrm{L}$ de $\mathrm{CTAB} / \mathrm{NaCl}$ a cada tubo, sendo feita uma nova incubação por $10 \mathrm{~min}$ a $65^{\circ} \mathrm{C}$. À mistura foram adicionados $4 \mathrm{~mL}$ de CIA (clorofórmio isoamil), sendo a mesma centrifugada a $4000 \mathrm{~g}$ por $5 \mathrm{~min}$. O sobrenadante foi transferido para novos tubos, aos quais foram adicionados $4 \mathrm{~mL}$ de CIA. Nova centrifugação foi feita a $4000 \mathrm{~g}$ por $5 \mathrm{~min}$. Ao sobrenadante foram adicionados $2 \mathrm{~mL}$ de fenol e $2 \mathrm{~mL}$ de CIA e a mistura foi centrifugada a $4000 \mathrm{~g}$ por $5 \mathrm{~min}$. A seguir, o sobrenadante foi novamente transferido para outro tubo, sendo adicionado $4 \mathrm{~mL}$ de CIA. Após nova centrifugação a $4000 \mathrm{~g}$ por $5 \mathrm{~min}$ foram adicionados $2 \mathrm{~mL}$ de isopropanol. A mistura permaneceu no gelo por $1 \mathrm{~h}$. Terminado esse processo, as amostras foram centrifugadas a $12000 \mathrm{~g}$ por $10 \mathrm{~min}$, o sobrenadante foi descartado e, ao precipitado foram adicionados $8 \mathrm{~mL}$ de etanol $70 \%$. O material foi mantido durante 30 min no gelo e, após esse período, centrifugado por 10 min a $4000 \mathrm{~g}$. O álcool foi descartado, os tubos colocados invertidos sobre papel toalha e após estarem devidamente secos, os precipitados foram ressuspendidos em $200 \mu \mathrm{L}$ de tampão $1 \mathrm{X}$ TE. Alíquotas de $2 \mu \mathrm{L}$ do DNA total extraído foram diluídas em água destilada deionizada e usadas como modelo para as reações de PCR. O restante foi armazenado a $-20^{\circ} \mathrm{C}$.

As soluções tampão utilizadas na extração de DNA foram preparadas da seguinte maneira:

- Tampão de extração I: $5,42 \mathrm{~g}$ de $\mathrm{K}_{2} \mathrm{HPO}_{4}-3 \mathrm{H}_{2} \mathrm{O} ; 1,02 \mathrm{~g}$ de $\mathrm{KH}_{2} \mathrm{PO}_{4} ; 25 \mathrm{~g}$ de sucrose; 0,375 $\mathrm{g}$ de BSA e $5 \mathrm{~g}$ de PVP-10 (material para $250 \mathrm{~mL}$ ). Dissolução em agitador magnético e manutenção a $4{ }^{\circ} \mathrm{C}$. 
- Tampão de extração II: $6 \mathrm{~g}$ de Tris base; 7,3 g de NaCl e 18,6 g de EDTA; pH 8,0 (material para $500 \mathrm{~mL}$ ). Esterilização em autoclave e armazenamento à temperatura ambiente.

- Tampão TE: 60,5 g de Tris base; 18,6 g de EDTA; pH 8,0 e água destilada para completar volume para $500 \mathrm{~mL}$. Esterilização em autoclave e armazenamento à temperatura ambiente.

\subsubsection{Condições de PCR e padrões}

Para detecção de fitoplasma foi feita a amplificação de uma determinada seqüência do DNA genômico destes organismos, correspondente ao 16S rDNA, usando duplo PCR. Oligonucleotídeos ("primers"/iniciadores) universais, específicos para fitoplasmas (R16 mF2/mR1 e R16 F2n/R2) foram empregados em duplo PCR. Amostras de ácido nucléico obtidas das plantas supostamente infectadas foram usadas como modelo para a reação. As amostras de DNA provenientes de plantas de chuchu, comprovadamente infectadas por fitoplasma foram usadas como padrão positivo. Para os padrões negativos foram usados água e DNA total extraído de plantas sadias. Cada reação de PCR foi processada com um volume de $19 \mu \mathrm{L}$ de água destilada

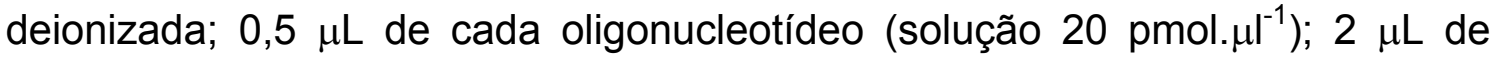
solução de deoxinucleotídeo trifosfato (solução $2,5 \mathrm{mM}$ de cada nucleotídeo); 2,5 $\mu \mathrm{L}$ de tampão de PCR (10X); 0,12 $\mu \mathrm{L}$ de Amplitaq 5 U. $\mu \mathrm{L}^{-1}$ e $1 \mu \mathrm{L}$ de DNA total extraído da planta, num volume final de $25 \mu \mathrm{L}$. O termociclador onde foram processadas as reações foi programado para um total de 35 ciclos, usando as seguintes etapas: 1 min a $94{ }^{\circ} \mathrm{C}$ para a desnaturação do ácido nucléico, 2 min a $50^{\circ} \mathrm{C}$ para a hibridização e 3 min a $72^{\circ} \mathrm{C}$ para a fase de extensão. Um tempo adicional de 1 e 7 min foram permitidos para a etapa de desnaturação do primeiro ciclo e para a extensão do último ciclo, respectivamente. O DNA amplificado com o par de oligonucleotídeos R16 mF2/mR1 foi diluído (1:50) em água destilada deionizada e usado como modelo para a re-amplificação com o par R16 F2n/R2 (Figura 1), seguindo as mesmas condições acima descritas. 


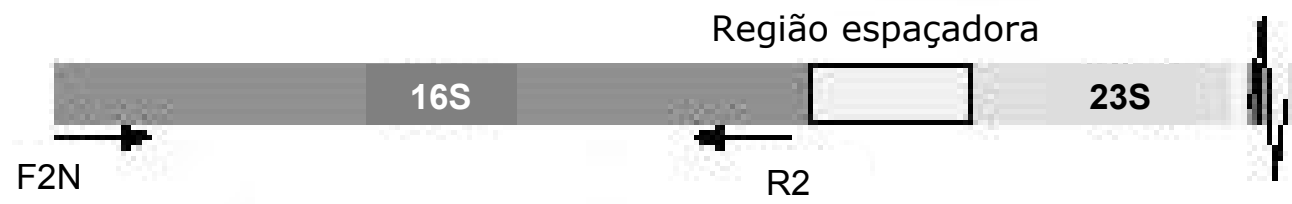

F2n/R2 = par de "primer" usado em duplo PCR

Figura 1 - Posição do par R16 F2n/R2 no gene 16S rDNA

\subsection{Identificação de fitoplasma por PCR}

\subsubsection{Uso de oligonucleotídeos específicos para classificação em grupos}

O fitoplasma detectado nas amostras EB01, EB02 e ET02, de plantas sintomáticas, foi identificado pela técnica de duplo PCR, através do uso de iniciadores específicos para fitoplasmas representantes dos grupos $16 \mathrm{Srl}$ (grupo do fitoplasma causador de "aster yellows"), 16Srlll (grupo do fitoplasma causador de "X-disease") e 16SrV (grupo do fitoplasma causador de "elm yellows").

Os produtos de PCR da primeira amplificação, conduzida com par de oligonucleotídeos $\mathrm{R} 16 \mathrm{mF} 2 / \mathrm{mR} 1$, foram diluídos (1:50) em água destilada deionizada e submetidos à re-amplificação usando pares de iniciadores específicos para fitoplasmas dos grupos 16Srl [R16(I)F1/R16(I)R1]; 16SrIII [R16(III)F2/R16(III)R1] e 16SrV [R16(V)F1/R16(V)R1].

\subsection{Oligonucleotídeos}

As seqüências dos oligonucleotídeos utilizados encontram-se abaixo descritas:

* Oligonucleotídeos universais (Gundersen \& Lee, 1996):

R16 mF2 - 5'CAT GCA AGT CGA ACG A 3'

R16 mR1 - 5'CTT AAC CCC AAT CAT CGA C 3' 
R16 F2n - 5' GAA ACG ACT GCT AAG ACT GG 3'

R16 R2 - 5' TGA CGG GCG GTG TGT ACA AAC CCC G 3'

* Oligonucleotídeos específicos (Lee et al., 1994):

R16(I)F1 - 5' TAA AAG ACC TAG CAA TAG G 3'

R16(I)R1 - 5' CAA TCC GAA CTG AGA CTG T 3'

R16(III)F2 - 5' AAG AGT GGA AAA ACT CCC 3'

R16(III)R1 - 5' TCC GAA CTG AGA TTG A 3'

R16(V)F1 - 5' TTA AAA AGA CTT CTT CGG 3'

R16(V)R1 - 5' TTC AAT CCG TAC TGA GAC TAC C 3'

\subsection{Eletroforese em gel de agarose e marcador molecular}

Todos os produtos de re-amplificação foram analisados através de eletroforese em gel de agarose (1\%), tampão TA 1X e voltagem constante de $65 \mathrm{~V}$ por $90 \mathrm{~min}$. Após a corrida, o gel foi submetido à coloração em brometo de etídeo, durante $10 \mathrm{~min}$ e posterior lavagem em água destilada por $10 \mathrm{~min}$. A visualização das bandas de DNA foi feita em transiluminador de luz ultravioleta. $\mathrm{O}$ marcador molecular utilizado foi $1 \mathrm{~Kb}$ ladder.

\subsection{Microscopia eletrônica de transmissão}

Amostras de tecido de plantas de tomate e berinjela foram submetidas à exame através de microscopia eletrônica de transmissão.

Para tal, fragmentos das hastes de plantas sintomáticas e de plantas sadias foram fixados em fixador Karnovsky modificado e pós-fixados em solução de tetróxido de ósmio 1\%. Após contrastação "en bloc" com acetato de uranila $0,5 \%$ por uma noite, as amostras foram desidratadas em série de acetona e emblocadas em resina Spurr. Em seguida, procedeu-se ao seccionamento em ultramicrótomo Leika Ultracut UCT. As secções prateadas (70-80 nm) foram coletadas, depositadas em telinhas de cobre, contrastadas com acetato de uranila e citrato de chumbo, seguindo protocolo descrito por Kitajima \& Nome (1999). Os tecidos do floema dessas amostras foram 
observados em microscópio eletrônico Zeis EM 900 do Núcleo de Apoio à Pesquisa em Microscopia Eletrônica Aplicada à Agricultura (NAP/MEPA) da ESALQ/USP.

\subsection{Teste de transmissão por enxertia}

Seis plantas de berinjela sadias, provenientes de sementes, foram enxertadas com plantas sintomáticas, por garfagem ou enxertia de topo. As plantas enxertadas foram colocadas em câmara úmida por 10 dias e, em seguida, transferidas para casa de vegetação onde foram mantidas à temperatura aproximada de $25^{\circ} \mathrm{C}$. A enxertia foi utilizada como uma alternativa aos "Postulados de Koch", numa tentativa de reproduzir os sintomas observados em campo e dessa maneira, comprovar a patogenicidade do patógeno.

\subsection{Identificação de fitoplasma por análise de RFLP}

\subsubsection{Caracterização do fitoplasma}

As seqüências amplificadas pelo duplo PCR com o uso dos iniciadores universais, indicando a presença de fitoplasma nas plantas, foram analisadas através do uso de enzimas de restrição. Uma alíquota de $4 \mu \mathrm{L}$ de cada produto de PCR foi digerida, separadamente, por diferentes endonucleases, seguindo as instruções do fabricante, durante um período de aproximadamente $30 \mathrm{~h}$ a $36^{\circ} \mathrm{C}$. As enzimas Alul, Hhal, Hpall, Kpnl, Msel, Rsal e Mbol foram utilizadas na identificação do fitoplasma detectado pela técnica de duplo PCR, para confirmação de resultados dos testes de grupo específico.

\subsubsection{Enzimas de restrição}

Abaixo, encontram-se descritas as enzimas de restrição (endonucleases) utilizadas, com suas respectivas seqüências de corte:

- Alul: AG $\vee C T$ 
- Hhal: GCG $\vee C$

- Hpall: C $\checkmark C G G$

- Kpnl: GGTAC $\vee C$

- Msel: T\TAA

- Rsal: GT $\checkmark A C$

- Mbol: $\checkmark G A T C$

\subsubsection{Eletroforese em gel de poliacrilamida, marcador molecular e modo de análise dos resultados}

Os produtos da digestão enzimática foram separados por eletroforese em gel de poliacrilamida (4,5\%), tampão TBE 1X, voltagem inicial de $220 \mathrm{~V}$ durante 5 min e em seguida voltagem constante de $150 \mathrm{~V}$ por $45 \mathrm{~min}$. O gel foi colorido em brometo de etídeo e os fragmentos de DNA gerados, foram visualizados em transiluminador de luz ultravioleta e fotografados. $O$

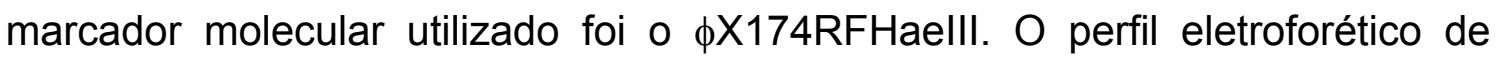
cada fitoplasma foi comparado aos padrões existentes na literatura (Lee et al., 1998; Davis et al., 1998; Montano et al., 2000; Barros et al., 2002) e com base nestes resultados foi feita a identificação do fitoplasma, classificando-o em um dos 15 grupos, existentes para este tipo de fitopatógeno.

\subsection{Sequenciamento}

Os produtos do duplo PCR das amostras EB01, EB02 e ET02 foram clonados em Escherichia coli usando o kit de clonagem pGEM T Easy Vector System I (Promega) de acordo com as instruções do fabricante. Os fragmentos de 1,2 Kb clonados foram sequenciados e através das seqüências nucleotídicas do 16S rDNA, foram comparados entre si e com seqüências de isolados de outros países. Assim sendo, foi possível demonstrar o nível de identidade genética existente entre eles. 


\subsubsection{Purificação do DNA}

Para a purificação de DNA foi usado o "kit" de purificação GFX ${ }^{T M}$ PCR DNA. A coluna GFX ${ }^{\mathrm{TM}}$ (com filtro) foi colocada no tubo coletor, onde foram adicionados $500 \mu \mathrm{L}$ de tampão de captura e $60 \mu \mathrm{L}$ da solução de DNA. A solução final foi ressuspendida com micropipeta (4 a 6 vezes) e as amostras foram centrifugadas à velocidade de $14000 \mathrm{~g}$ por $30 \mathrm{~s}$. O sobrenadante do tubo coletor foi descartado, a coluna GFX ${ }^{\mathrm{TM}}$ foi recolocada no tubo coletor e a ela foram adicionados $500 \mu \mathrm{L}$ de tampão de lavagem ("Wash buffer"). As amostras foram centrifugadas à velocidade máxima por $30 \mathrm{~s}$, o tubo coletor foi descartado e a coluna GFX ${ }^{T M}$ foi transferida para um microtubo de $1,5 \mathrm{~mL}$. No centro do filtro da coluna GFX ${ }^{\mathrm{TM}}$ foram colocados $20 \mu \mathrm{L}$ de água destilada deionizada e as amostras foram incubadas à temperatura ambiente por $1 \mathrm{~min}$. Após esse período as amostras foram centrifugadas à velocidade de $14000 \mathrm{~g}$ com os microtubos abertos. Os produtos finais (DNAs purificados) foram armazenados para posterior utilização. Uma corrida eletroforética foi realizada, com $1 \mu \mathrm{L}$ do DNA purificado juntamente com $1 \mu \mathrm{L}$ de tampão de carregamento, para visualização das bandas e quantificação das mesmas.

\subsubsection{Ligação ao vetor plasmidial}

Para essa etapa, que visa ligar o DNA purificado ao vetor plasmidial com o uso do Kit pGEM T Easy Vector System I (Promega), foi preparada a seguinte reação: $3.0 \mu \mathrm{L}$ do DNA purificado, $0,5 \mu \mathrm{L}$ do vetor $\left(25 \mathrm{ng} . \mu \mathrm{L}^{-1}\right), 5,0 \mu \mathrm{l}$ de tampão ligase $2 \mathrm{X}, 1,0 \mu \mathrm{L}$ de T4 DNA ligase $\left(3 \mathrm{U} . \mu \mathrm{L}^{-1}\right)$ (enzima de clonagem) e $0,5 \mu \mathrm{L}$ de água destilada deionizada num total de $10 \mu \mathrm{L}$ de reação para a ligação, que foi colocada em microtubo e mantida por uma noite a $4{ }^{\circ} \mathrm{C}$. Após esse período, a reação de ligação foi colocada a $-20{ }^{\circ} \mathrm{C}$ por uma manhã e a seguir transferida para células competentes (estirpe DH5 $\alpha$ de Escherichia coli). 


\subsubsection{Transformação de células competentes por choque térmico e extração do DNA plasmidial}

Para a transformação foram adicionados $10 \mu \mathrm{L}$ do produto da ligação em $100 \mu \mathrm{L}$ de células competentes de $E$. coli, estirpe $\mathrm{DH} 5 \alpha$ preparadas conforme Hanahan (1983) e a mistura foi colocada no gelo por 20 min. Após esse período, a solução foi submetida a choque térmico por incubação a $42{ }^{\circ} \mathrm{C}$ por exatamente $90 \mathrm{~s}$ e, imediatamente, transferida para o gelo por $2 \mathrm{~min}$. A seguir foram adicionados $900 \mu \mathrm{L}$ de meio SOC (1\% de triptona; $0,5 \%$ extrato de levedura; $8,5 \mathrm{mM} \mathrm{NaCl} ; 2,5 \mathrm{mM}$ de $\mathrm{KCl} ; 0,01 \mathrm{mM} \mathrm{MgCl}$; 0,02 mM de glicose, água q.s.p. $1000 \mathrm{~mL}$ ) às células transformadas que foram incubadas a $37^{\circ} \mathrm{C}$ por 1 hora e meia em agitador moderado (220 rpm). As células foram centrifugadas e $600 \mu \mathrm{L}$ do sobrenadante descartado. Uma alíquota de $200 \mu \mathrm{L}$ desse produto foi plaqueado em meio LB ( $1 \%$ de triptona; $0,5 \%$ de extrato de levedura; $0,25 \%$ de $\mathrm{NaCl} ; 4 \%$ de ágar), acrescido de ampicilina (100 $\mathrm{mg}^{\mathrm{mL}} \mathrm{mL}^{-1}$ ), X-gal (5-bromo-4-cloro-3-indolil- $\beta$-D-galactopiranosida) $50 \mathrm{mg} \cdot \mathrm{mL}^{-1}$ e IPTG (isopropil- $\beta$-D-tiogalactopiranosida) solução estoque, para avaliação da atividade de $\beta$-galactosidase nos transformantes visando selecioná-los. A placa foi mantida por uma noite em estufa a $37^{\circ} \mathrm{C}$ para a quantificação de colônias e seleção das células transformadas com DNA plasmidial recombinante. As colônias recombinantes com o fragmento de DNA inserido no sítio de clonagem exibiram a cor branca (produzindo $\beta$-galactosidase não-funcional), enquanto as colônias não recombinantes mostraram-se azuis (produzindo $\beta$-galactosidase funcional). O restante, que foi mantido em geladeira, foi plaqueado no dia seguinte. Os clones obtidos foram preservados, acrescentando um volume de $100 \mu \mathrm{L}$ de glicerol (50\%) ao meio inoculado e armazenados a $-80^{\circ} \mathrm{C}$.

A extração dos plasmídeos para posterior sequenciamento de seus insertos foi realizada em placas de crescimento para 96 amostras pelo método da lise alcalina (Sambrook et al., 1989). 


\subsubsection{Reação de PCR para sequenciamento}

O DNA plasmidial extraído de cada clone foi submetido à técnica de PCR para sua amplificação. A mistura para a reação de PCR para sequenciamento foi composta por $1,0 \mu \mathrm{L}$ de DNA (aproximadamente $200 \mathrm{ng}$ ); 2,0 $\mu \mathrm{L}$ de Big Dye $^{\mathrm{TM}}$ [solução com tampão, taq, deoxinucleotídeo trifosfato (dntps) e deoxinucleotídeo trifosfato marcados (ddntps)]; 2,0 $\mu \mathrm{L}$ de tampão (2.5X); 1,0 $\mu \mathrm{L}$ do "primer" M13F ou M13R (3.2 pmoles. $\mu \mathrm{L}^{-1}$ ) e 4,0 $\mu \mathrm{L}$ de água destilada deionizada. $\mathrm{O}$ aparelho termociclador onde foram processadas as amostras foi programado para um total de 25 ciclos, sendo $10 \mathrm{~s}$ a $96{ }^{\circ} \mathrm{C}$ para a etapa de desnaturação do ácido nucléico, $5 \mathrm{~s}$ a $50^{\circ} \mathrm{C}$ para a hibridização e 4 min a $60^{\circ} \mathrm{C}$ para a fase de extensão do "primer".

Ao produto final da amplificação foram adicionados $40 \mu \mathrm{L}$ de isopropanol (75\%), incubando-o à temperatura ambiente durante $20 \mathrm{~min}$ e promovendo posterior centrifugação à velocidade de $4000 \mathrm{~g}$ por $20 \mathrm{~min}$. O precipitado foi lavado em $250 \mu \mathrm{L}$ de etanol $70 \%$ e submetido a centrifugação por $5 \mathrm{~min}$. O precipitado final foi colocado à temperatura de $90^{\circ} \mathrm{C}$ por $1 \mathrm{~min}$ e ressuspendido em $3 \mu \mathrm{L}$ de tampão de carregamento (formamida). As amostras foram homogeneizadas em agitador de tubos por $15 \mathrm{~s}$, centrifugadas e uma alíquota de $1,5 \mu \mathrm{L}$ de cada amostra foi utilizada para o sequenciamento.

\subsubsection{Seqüência de nucleotídeos e análise}

O sequenciamento foi conduzido no Laboratório de Genética Molecular Aplicada a Fitopatologia, pertencente ao setor de Fitopatologia da ESALQ/USP. As alíquotas de $1,5 \mu \mathrm{L}$ de cada amostra (fragmentos clonados amplificados), foram submetidas ao sequenciador automático $\mathrm{ABI}$ Prism 377 DNA Sequencer ${ }^{\mathrm{IM}}$ (PE Applied Biosystems) por $10 \mathrm{~h}$, segundo protocolo descrito pelo fabricante.

Os fragmentos clonados e amplificados foram sequenciados no sentido 5' - 3' e 3' - 5'. As seqüências de nucleotídeos dos fragmentos provenientes do 
mesmo isolado foram alinhadas, através do programa DNA Sequencher 3.0 (Gene Codes Corporation) e editadas manualmente, quando necessário, por observação do eletroferograma, levando-se em conta critérios préestabelecidos para a obtenção das seqüências consenso de cada fragmento clonado. Uma árvore filogenética foi construída, através do programa CLUSTALW (Multiple Sequence Alignment), pelo método "Neighbor-Joining", comparando os fragmentos clonados obtidos, com seqüências de isolados depositadas no "GenBank". Além disso, mapas de restrição foram gerados virtualmente pelas enzimas $\mathrm{Hhal}$, Rsal, Mbol, Alul, e Hpall, com as seqüências dos fragmentos clonados provenientes das amostras EB01, EB02 e ET02, através do programa DNA Sequencher 3.0 (Gene Codes Corporation), permitindo compará-los. 


\section{RESULTADOS E DISCUSSÃO}

\subsection{Sintomatologia e teste de transmissão}

As plantas de tomate e berinjela amostradas no campo, exibiram sintomas típicos de doença de natureza fitoplasmática, tais como enfezamento generalizado, clorose foliar acentuada, superbrotamento de ramos, encurtamento de entre-nós, redução no tamanho de folhas, flores e frutos, bem como deformação do cálice (Figuras 2 a 7).

A clássica prova de patogenicidade para esses agentes, ou seja, a realização das etapas dos "Postulados de Koch", não tem sido possível, uma vez que os fitoplasmas não são cultiváveis em meio de cultura. Assim, para demonstrar a patogenicidade destes agentes, é necessário recorrer a alternativas como transmissão através de insetos vetores ou união de tecidos. No presente trabalho, as seis plantas de berinjela sadias, provenientes de sementes, passaram a exibir sintomas típicos da doença, aproximadamente três a quatro semanas após terem sido enxertadas experimentalmente com plantas doentes, em condições de casa de vegetação. Esta sintomatologia apresentada comprova que o fitoplasma associado à planta sintomática foi transmitido através de união de tecidos. 


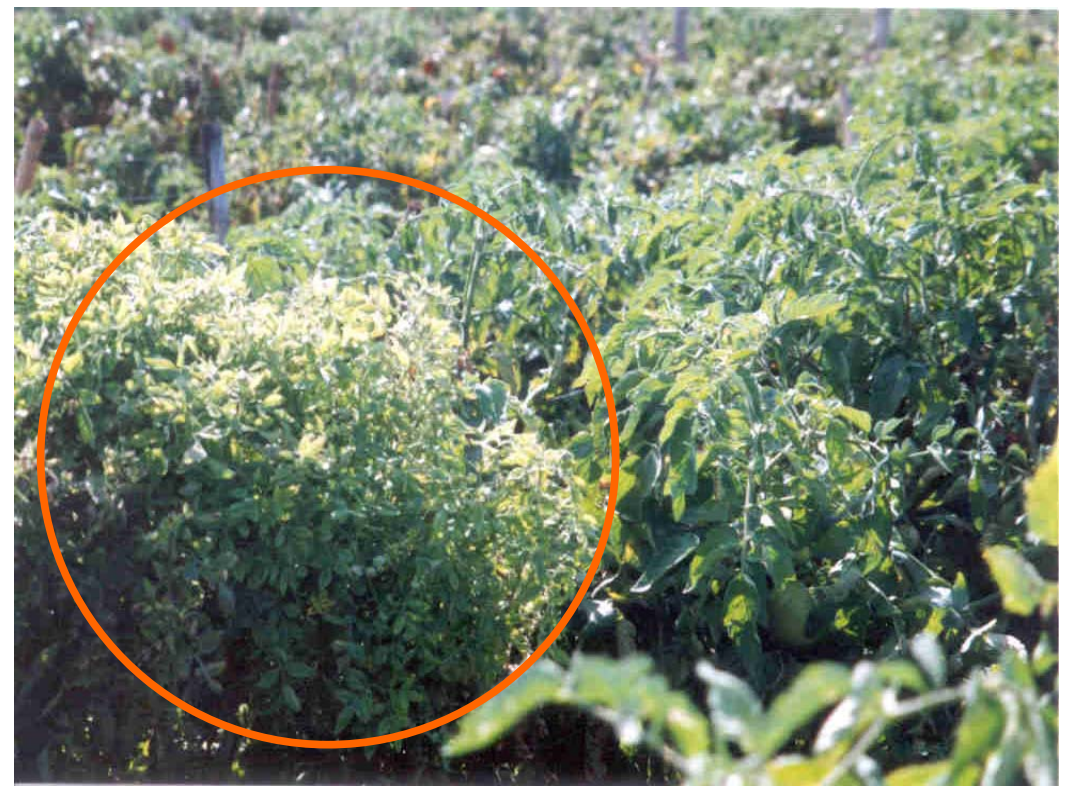

Figura 2 - Sintomas de enfezamento e clorose foliar acentuada em tomateiro, observados no campo

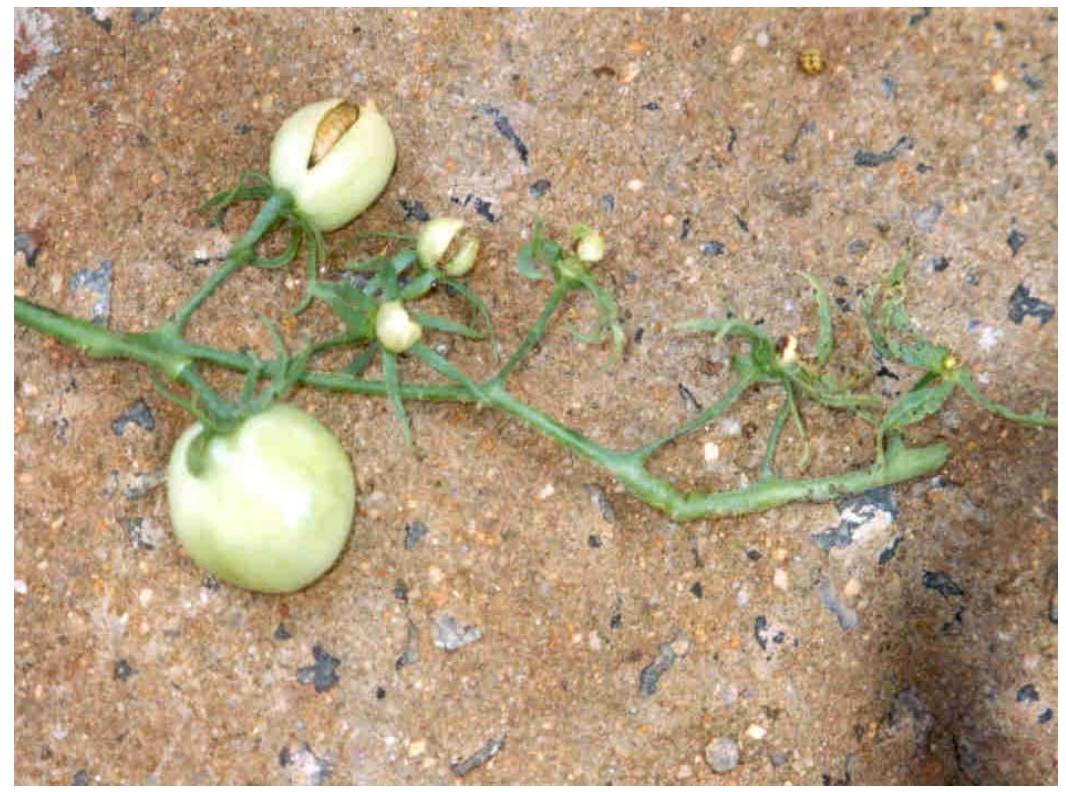

Figura 3 - Redução no tamanho de frutos em tomateiro 


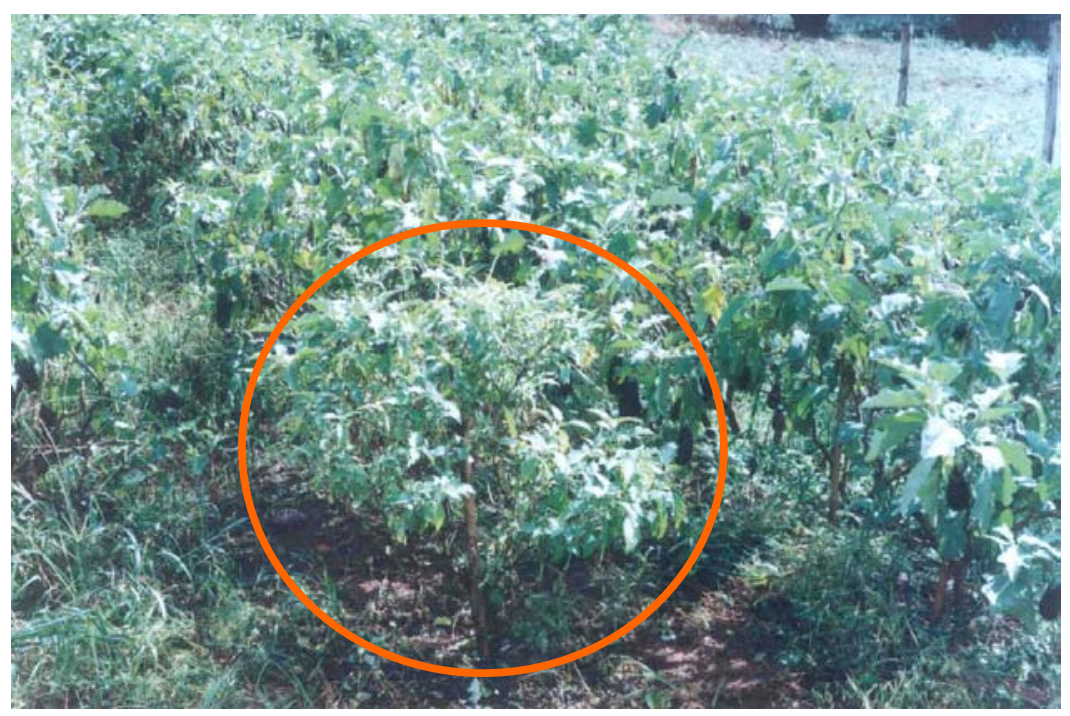

Figura 4 - Sintomas de enfezamento generalizado, observado no campo, em planta de berinjela

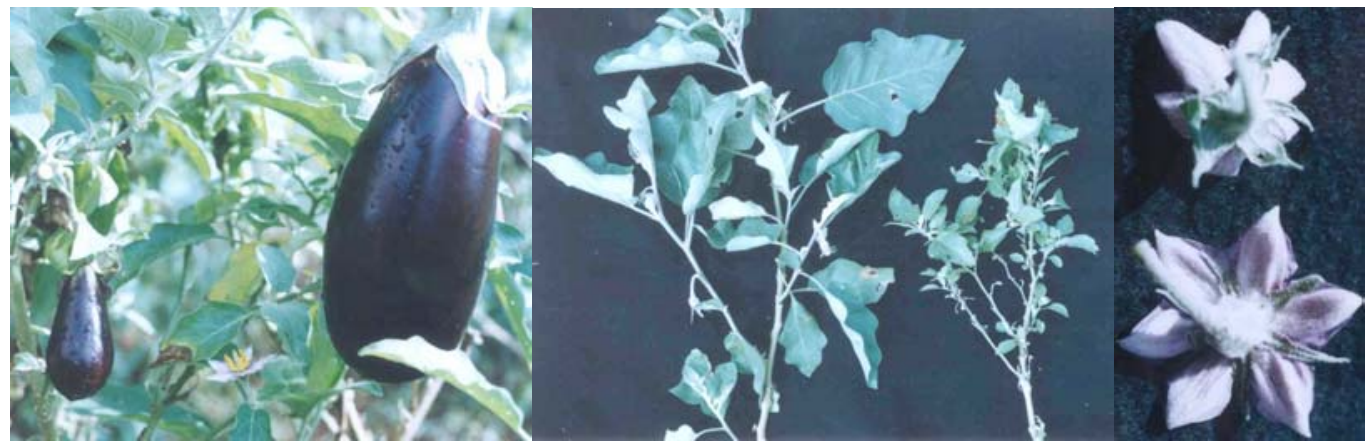

Figura 5 - Redução no tamanho de frutos, folhas e flores em berinjela 


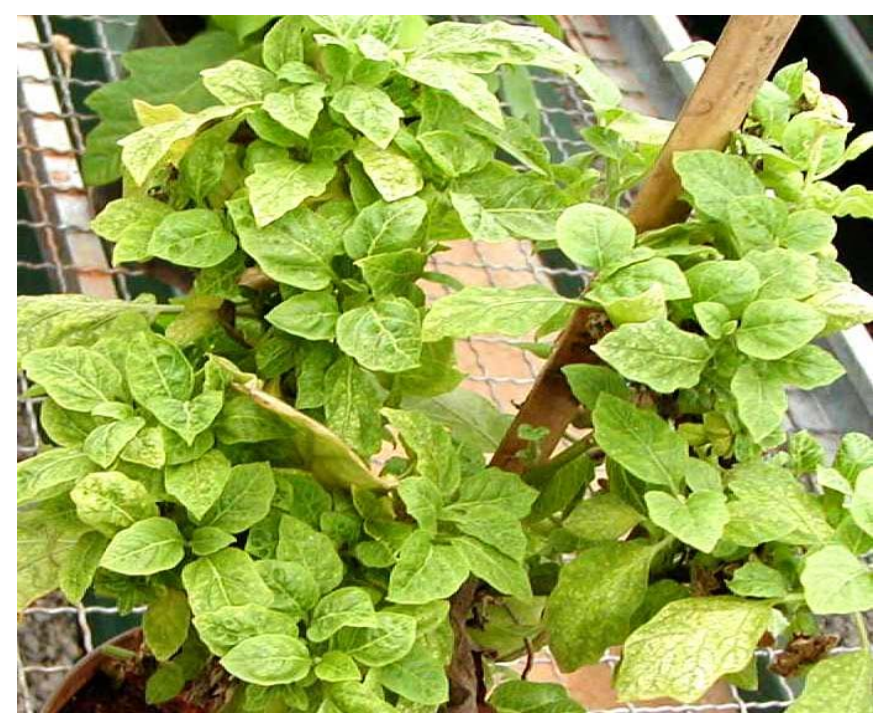

Figura 6 - Planta de berinjela enxertada experimentalmente exibindo sintomas típicos de doenças de natureza fitoplasmática, como clorose acentuada, superbrotamento de ramos e redução no tamanho das folhas

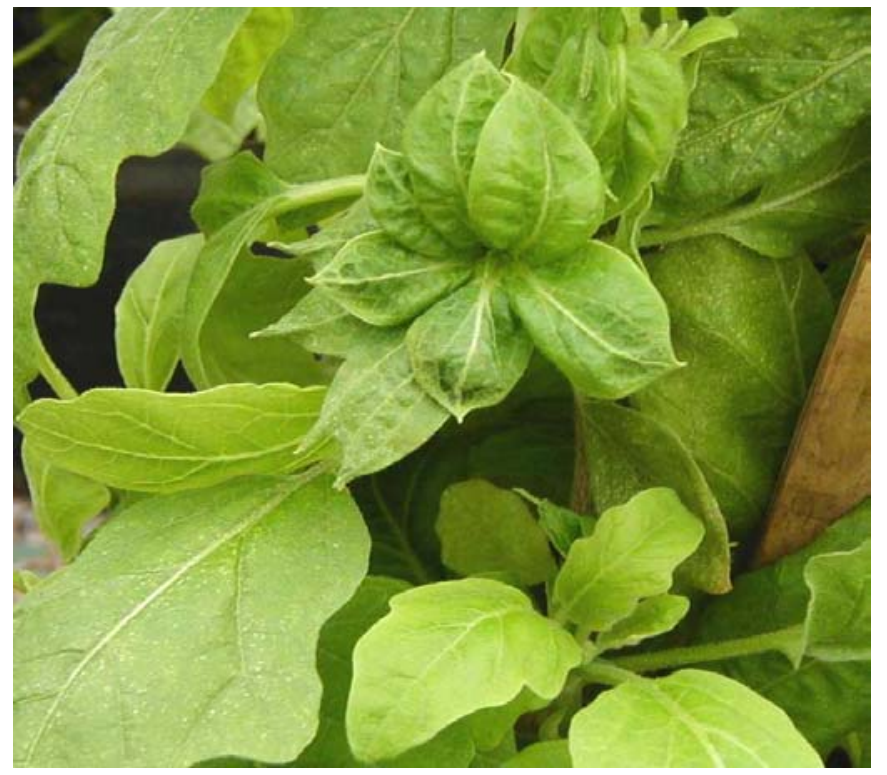

Figura 7 - Deformação do cálice em berinjela enxertada experimentalmente 


\subsection{Detecção através de duplo PCR}

Os fragmentos do $16 \mathrm{~S}$ rDNA do fitoplasma foram amplificados pelo par de iniciadores R16 mF2/mR1 e re-amplificados pelo par R16 F2n/R2. Estas amplificações foram visualizadas na forma de bandas de aproximadamente 1,2 $\mathrm{Kb}$, demonstrando a presença de fitoplasma nas amostras EB01, EB02 e ET02 originárias de plantas sintomáticas. Os mesmos resultados foram obtidos para o padrão positivo representado pelo DNA extraído de planta de chuchu comprovadamente infectadas por fitoplasma. Nenhuma amplificação ocorreu para os padrões negativos representados pela água e por plantas de tomate e berinjela assintomáticas.

Um fragmento de $1,2 \mathrm{~Kb}$ foi amplificado a partir das amostras obtidas das plantas de berinjela enxertadas, confirmando dessa forma a presença do patógeno nos tecidos da planta doente. Assim ficou demonstrado, através de método molecular, a transmissão do fitoplasma por meio de enxertia.

\subsection{Identificação do fitoplasma através de PCR}

Os resultados da identificação através de PCR, mostraram a ocorrência de uma banda de $0,8 \mathrm{~Kb}$ visualizada no gel de agarose $(1 \%)$, demonstrando que um fitoplasma pertencente ao grupo 16Srlll (grupo do fitoplasma do "X-disease") estava presente nas amostras analisadas (Figura 8). Ausência de bandas foram constatadas nos PCRs conduzidos com os oligonucleotídeos específicos para identificação de fitoplasmas dos grupos 16Srl e 16SrV, embora os padrões positivos para estes grupos tivessem resultados positivos (Figura 8 ). 


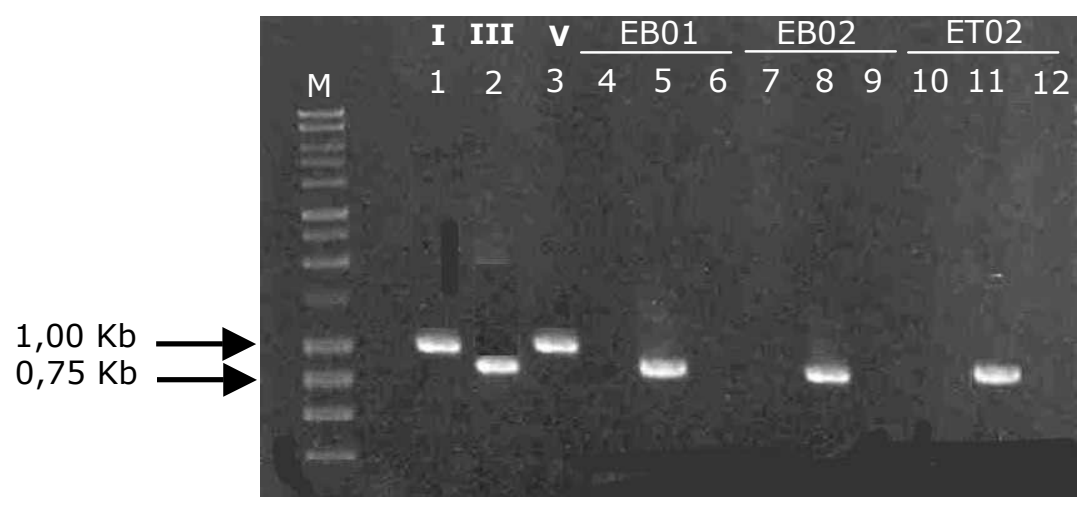

Figura 8 - Gel de agarose (1\%) para grupo específico, com bandas de 0,8 Kb, características de grupo 16Srlll, para os isolados das amostras EB01, EB02 e ET02 (colunas 5, 8 e 11). Na coluna 1, isolado proveniente de amostra sintomática de cana-de-açúcar, exibindo banda de 1,1 Kb para grupo $16 \mathrm{Srl}$; coluna $2 \mathrm{com}$ banda de isolado representante do grupo $16 \mathrm{Srlll}$ (Chuchu) e coluna 3 isolado proveniente de crotalária, com banda de $1,1 \mathrm{~Kb}$ para grupo $16 \mathrm{SrV}$. Nota-se nas colunas 4, 7 e 10 ausência de bandas para grupo 16Srl e nas colunas 6, 9 e 12 ausência de bandas para grupo 16SrV, nas amostras estudadas. $\mathrm{M}$ - marcador molecular $1 \mathrm{~Kb}$ ladder

\subsection{Microscopia eletrônica de transmissão}

Em preparações feitas a partir de tecido vegetal supostamente doente, foram constatados corpúsculos pleomórficos no floema das plantas de berinjela (Figura $9 \mathrm{~A}$ e B) e tomate (Figura 10) com sintomas típicos de enfezamento, o que indica a presença de fitoplasmas nesses tecidos.

A aplicação da microscopia eletrônica é bastante eficiente para a detecção de fitoplasmas, no entanto não permite a identificação destes Molicutes, uma vez que os mesmos são indistintos morfologicamente. Nesse estudo, a microscopia eletrônica revelou em todos os isolados estudados, corpúsculos pleomórficos de tamanhos variados e pequenas mudanças na forma. Uma possível explicação para essas variações foi relatada por Kitajima \& 
Costa (1967) que afirmaram que o fitoplasma passa por um ciclo de desenvolvimento durante o qual sofre alterações em sua morfologia.

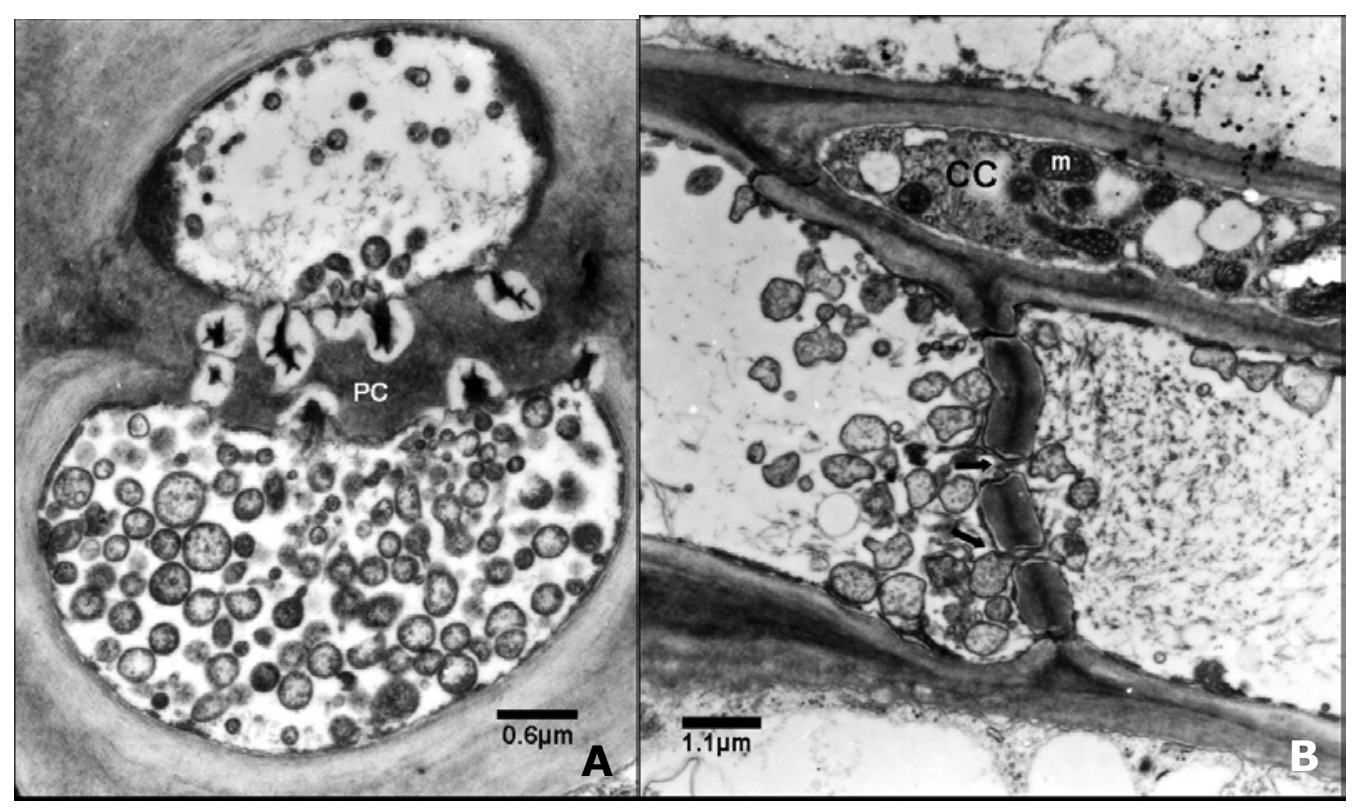

Figura 9 - (A) Dois elementos de floema de berinjela infectada seccionados transversalmente. Notar os corpúsculos pleomórficos no lúmen. Placa crivada (PC). (B) Elemento de vaso crivado do floema de berinjela infectada. Nota-se a presença de vários corpúsculos pleomórficos no lúmen, alguns dos quais atravessando a placa crivada (setas). Célula companheira (CC) e mitocôndria (m) 


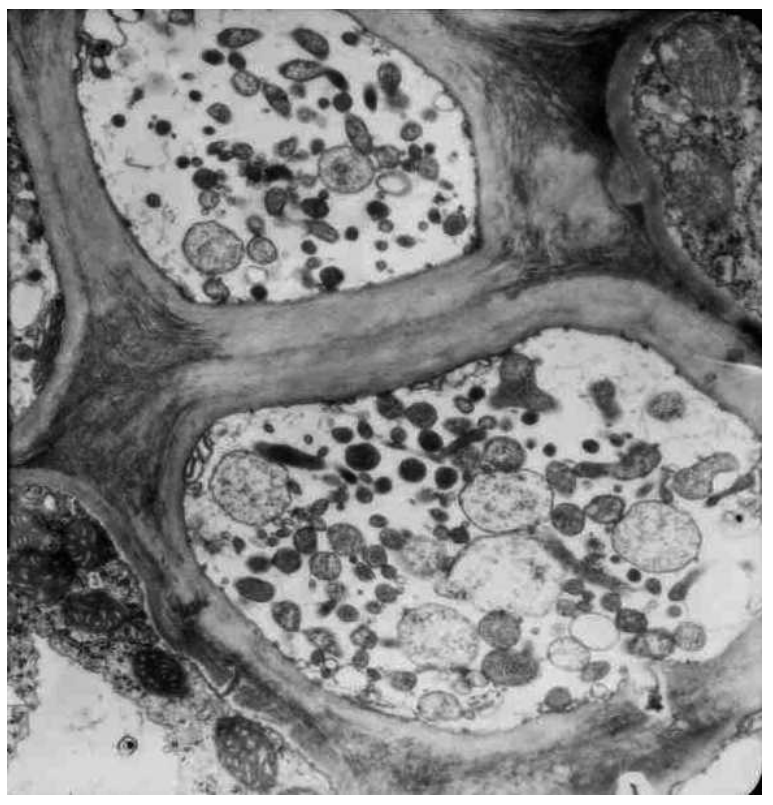

Figura 10 - Presença de corpúsculos pleomórficos no lúmen de elemento de vaso crivado no floema de tomateiro infectado

\subsection{Identificação através da análise por RFLP}

A análise de RFLP revelou que os fragmentos correspondentes ao 16S rDNA dos fitoplasmas amplificados a partir das amostras EB01, EB02 e ET02, quando digeridos com as enzimas Alul, Msel, Hpall e Mbol apresentaram padrões de restrição semelhante ao perfil apresentado pelo isolado proveniente de chuchu, representante do grupo 16Srlll, utilizado nesse trabalho (Figuras 11 A/B e 12). A comparação (Tabela 1) dos perfis eletroforéticos obtidos neste trabalho para estas enzimas, com os padrões de Lee et al. (1998) revelou que a enzima Alul praticamente não permite distinção entre subgrupos, sendo que apenas isolados do subgrupo $\mathrm{C}$ podem ser separados. A digestão com a enzima Msel permite distinguir os subgrupos A, C e D por apresentarem perfis eletroforéticos distintos dos demais subgrupos, portanto, através dessa enzima, foi observado que os isolados das amostras EB01, EB02 e ET02 não apresentaram padrões eletroforéticos para nenhum desses subgrupos. A enzima Hpall, no trabalho de Lee et al. (1998), mostra apenas dois padrões de 
perfil eletroforético para os subgrupos. Através dela, portanto, foi possível observar que os isolados estudados também não pertencem aos subgrupos $\mathrm{E} e$ G. Os isolados não apresentaram sítio de corte para a enzima Kpnl, que reconhece sítios de restrição para outros grupos específicos, como por exemplo, 16Srl. A enzima Rsal apresentou um perfil eletroforético para os isolados EB01 e ET02 distinto de todos os subgrupos relatados por Lee et al (1998), portanto, esses isolados parecem não pertencer aos subgrupos $A, B, C$, D, E e G. Já o isolado da amostra EB02 mostrou perfil diferente apenas do subgrupo G. Ainda, comparando os resultados com a literatura acima citada, os perfis eletroforéticos dos isolados EB02 e ET02 apresentados para a enzima Hhal foram completamente diferentes de todos os perfis observados em Lee et al. (1998), excluindo portanto, com o uso dessa enzima, a classificação desses dois isolados em qualquer um dos subgrupos descritos por eles. $O$ isolado EB01 apresentou um perfil parecido com o obtido por Lee et al. (1998) para isolado do subgrupo $\mathrm{E}$, sendo a combinação dos perfis dos isolados do subgrupo $A$ com subgrupo $C$ ou subgrupo $B$ com subgrupo $D$.

Com a enzima Rsal, os isolados das plantas EB01 e EB02 apresentaram padrões de restrição distintos quando comparados entre si. O isolado EB02 apresentou um padrão semelhante ao representante do grupo 16Srlll (chuchu) com 3 bandas. Os isolados EB01 e ET02 apresentaram o mesmo perfil entre si e quando comparados ao representante, mostraram um perfil semelhante, porém com uma banda extra (Figuras 11B e 12).

Após a digestão com a enzima Hhal os três isolados apresentaram perfis distintos comparados ao representante do grupo 16Srlll (Figura 13). Os isolados obtidos das amostras EB01 e EB02 mostraram-se diferentes entre si e o isolado proveniente da amostra ET02 apresentou-se idêntico ao perfil apresentado pelo isolado da amostra EB02. O isolado da amostra EB01 apresentou 3 bandas idênticas ao representante de grupo 16Srlll e uma banda extra. 
Para as enzimas Hhal e Rsal, a soma do tamanho dos fragmentos gerados foi superior ao tamanho do fragmento original de 1,2 Kb. As bandas adicionais observadas nos isolados podem ser explicadas pela presença de dois genes ribossômicos 16S, com pequenas diferenças, nas populações desses isolados, como proposto por Lee et al. (1993). Outra suposição seria a ocorrência de infecção mista, porém, os testes de duplo PCR com oligonucleotídeos específicos confirmaram a ocorrência apenas de fitoplasmas afiliados ao grupo 16Srlll nas amostras testadas (Figura 8), bem como a presença de um único padrão de restrição nas digestões com as outras enzimas. Os isolados oriundos das plantas EB01, EB02 e ET02, pertencem ao grupo $16 \mathrm{~S} r l l I$ não havendo, portanto, nas amostras testadas, a ocorrência de infecção mista.

Comparando os perfis eletroforéticos apresentados pela digestão com a enzima Hhal (Tabela 1) pode-se também excluir a possibilidade dos fitoplasmas encontrados em EB01, EB02 e ET02 pertencerem ao subgrupo J, cujo representante é o chuchu, utilizado nesse estudo.

Os resultados obtidos, indicaram a presença de duas ou mais populações de moléculas de RNA ribossomal nos isolados estudados, corroborando com os resultados obtidos por Barros (2002) para isolados provenientes de berinjela com cálice gigante e superbrotamento, que apresentaram padrões idênticos aos resultados obtidos neste trabalho. $O$ isolado da amostra ET02 mostrou-se idêntico ao isolado EBW (Tabela 1). Até o presente momento, fitoplasmas do grupo $16 \mathrm{~S} r$ III são considerados os mais diversos em relação a subgrupos (Davis et al., 1998; Lee et al., 1998; Montano et al., 2000; Barros et al., 2002). A variabilidade vista nos padrões de restrição observados reflete o grande número de subgrupos apresentados pelo grupo 16Srlll, e esta pode ser explicada pela presença de duas ou mais populações heterogêneas de moléculas para o gene do 16S rRNA, em alguns fitoplasmas (Davis, citado por Barros 2002). 

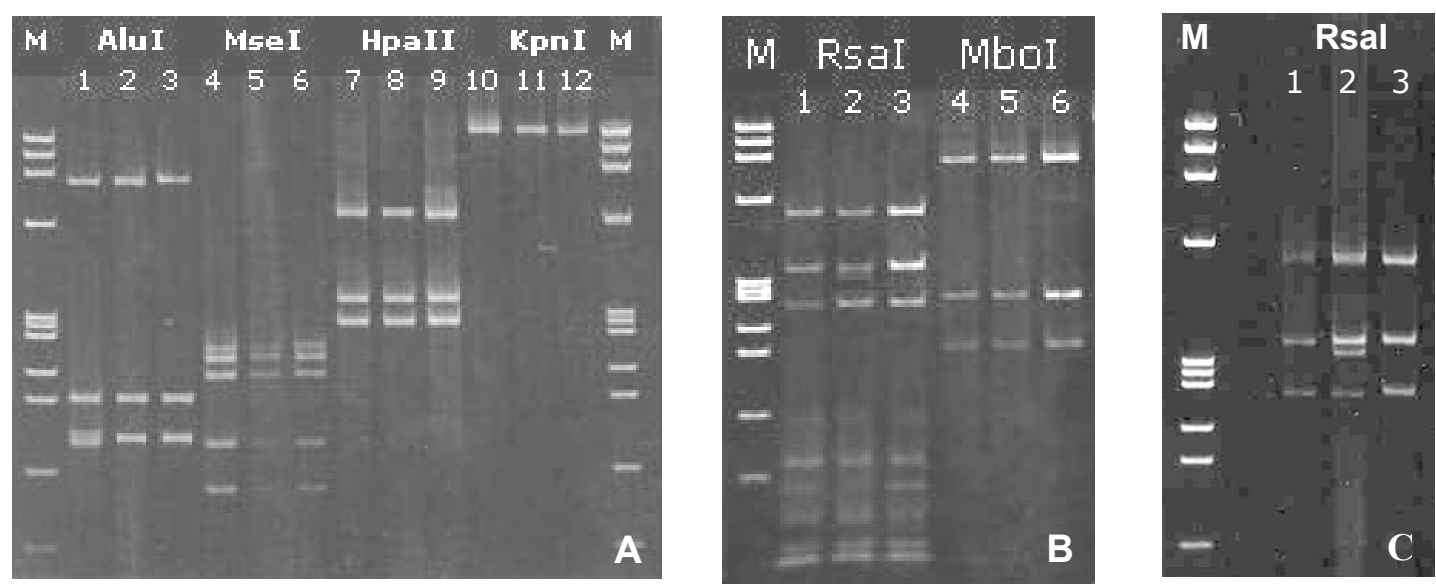

Figura 11 - Produtos de digestão enzimática com as endonucleases Alul, Msel, Hpall, Kpnl (A), Rsal e Mbol (B). Análise dos produtos de duplo PCR conduzido com os pares de oligonucleotídeos R16 mF2/mR1 e R16 F2n/R2, utilizando DNA extraído de plantas de chuchu com sintomas de superbrotamento, como representante do grupo 16Srlll e DNA extraído de plantas de berinjela (EB01 e EB02) com sintomas de enfezamento. (A) Colunas 1, 4, 7 e 10: representante grupo 16Srlll. Colunas 2, 5, 8 e 11: amostras de EB01. Colunas 3, 6, 9 e 12: amostras de EB02. (B): Colunas 1 e 4: representante grupo 16Srlll. Colunas 2 e 5: amostras de EB01 e colunas 3 e 6 : amostras de EB02. (C) Detalhe da enzima Rsal. M - padrão de peso molecular, utilizando o marcador $\phi X 174$ RFHaelll (1353pb, 1078pb, 872pb, 603pb, 310pb, 271pb, 281pb, 234pb, 194pb, 118pb, $72 \mathrm{pb})$ 


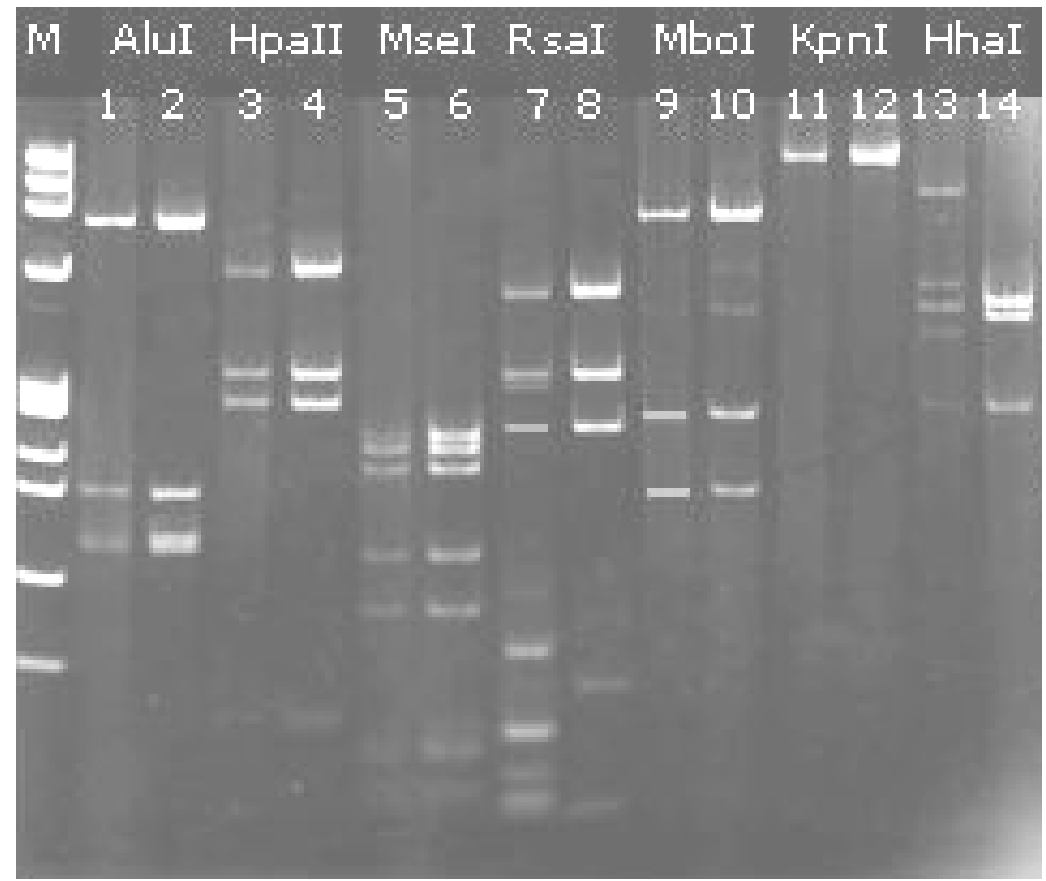

Figura 12 - Produtos de digestão enzimática com as endonucleases Alul, Hpall, Msel, Rsal, Mbol, Kpnl e Hhal. Análise dos produtos de duplo PCR conduzido com os pares de oligonucleotídeos R16 mF2/mR1 e R16 F2n/R2, utilizando DNA extraído de planta de chuchu com sintomas de superbrotamento, como representante do grupo 16Srlll e DNA extraído da amostra ET02, proveniente de tomateiro com sintomas de enfezamento. M - padrão de peso molecular, utilizando o marcador $\phi X 174 R F H a e l l l$ (1353pb, 1078pb, 872pb, 603pb, 310pb, $271 \mathrm{pb}, 281 \mathrm{pb}, 234 \mathrm{pb}, 194 \mathrm{pb}, 118 \mathrm{pb}, 72 \mathrm{pb})$. Colunas 1, 3, 5, 7, 9 , 11 e 13: amostras de ET02. Colunas 2, 4, 6, 8, 10, 12 e 14: representante grupo $16 \mathrm{SrllI}$ 


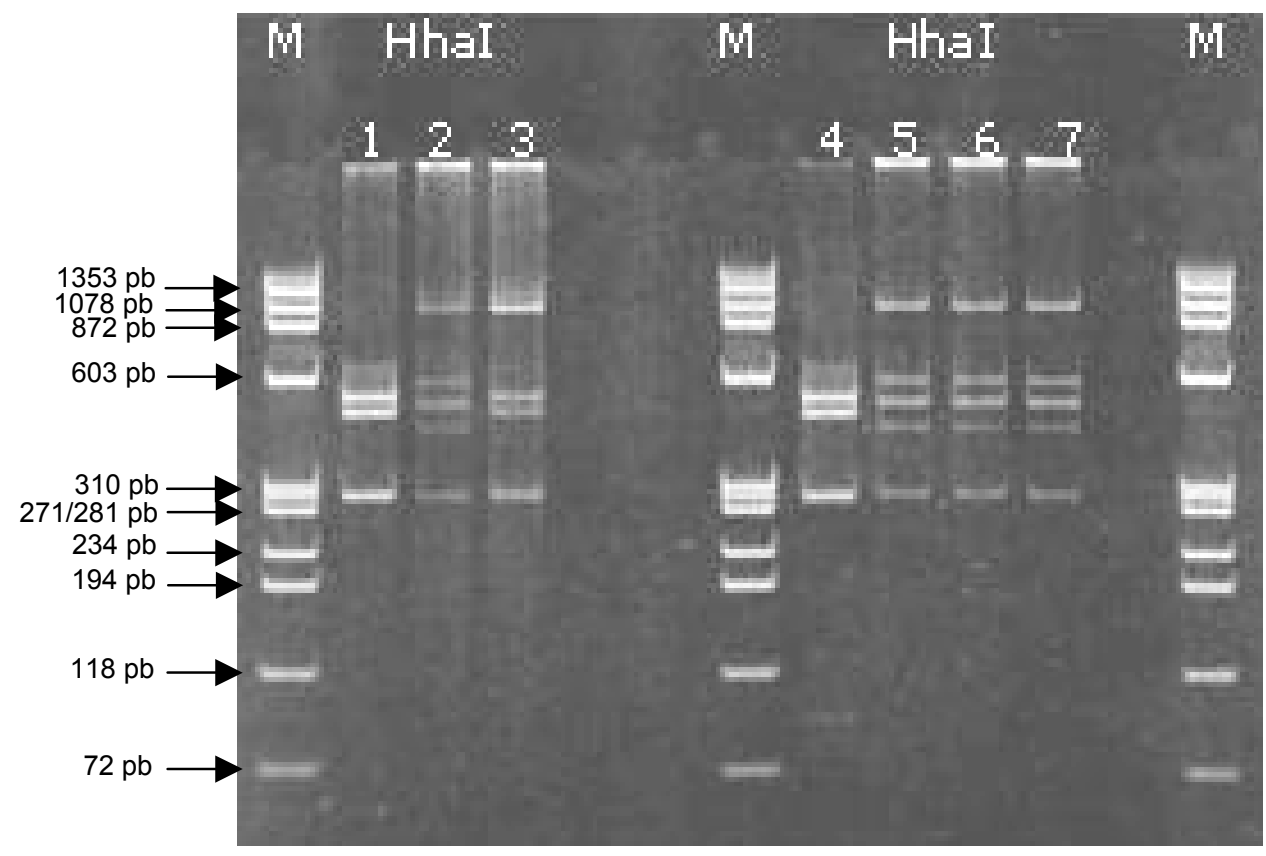

Figura 13 - Produtos de digestão enzimática com a endonuclease Hhal. Análise dos produtos de duplo PCR conduzido com os pares de oligonucleotídeos R16 mF2/mR1 e R16 F2n/R2, utilizando DNA extraído de planta de chuchu com sintomas de superbrotamento, como representante do grupo 16 Srlll e DNAs extraídos das plantas de berinjela (EB01 e EB02) e tomate (ET02) com sintomas de enfezamento. $\mathrm{M}$ - padrão de peso molecular, utilizando o marcador $\phi X 174 R F H a e l l I$. Colunas 1 e 4: representante grupo 16Srlll. Coluna 2: amostra EB02. Coluna 3: amostra EB01. Colunas 5, 6 e 7: amostras de ET02

Observando os dados da tabela 1, pode-se excluir a possibilidade dos isolados das amostras EB01, EB02 e ET02 pertencerem aos subgrupos $\mathrm{He}$ I, comparando os padrões deste trabalho com aqueles obtidos por Davis et al. (não publicado, citado por Barros, 2002) e Davis et al. (1998). Por esta análise de RFLP, baseada nos padrões de restrição, apresentados pelas enzimas Rsal e Hhal é possível sugerir que os fitoplasmas encontrados nas amostras 
estudadas, pertençam a subgrupos distintos dos observados dentro do grupo 16Srlll.

Tabela 1. Comparação dos padrões de perfil eletroforético dos isolados das amostras EB01, EB02, ET02 com outros fitoplasmas afiliados ao grupo 16Srlll obtidos através de análise de RFLP

\begin{tabular}{|c|c|c|c|c|c|c|c|c|}
\hline \multirow{2}{*}{\multicolumn{2}{|c|}{$\begin{array}{l}\text { Fitoplasma - } 16 \text { Srlll } \\
\text { (subgrupo) }\end{array}$}} & \multicolumn{7}{|c|}{ Padrões de restrição obtidos com as enzimas } \\
\hline & & \multirow{2}{*}{$\begin{array}{c}\text { Alul } \\
1\end{array}$} & \multirow{2}{*}{$\begin{array}{c}\text { Mbol } \\
2\end{array}$} & \multirow{2}{*}{$\begin{array}{c}\text { Hpall } \\
2\end{array}$} & \multirow{2}{*}{$\begin{array}{c}\text { Msel } \\
2\end{array}$} & \multirow{2}{*}{$\begin{array}{c}\text { Rsal } \\
1\end{array}$} & \multirow{2}{*}{$\begin{array}{c}\text { Hhal } \\
4\end{array}$} & \multirow{2}{*}{$\begin{array}{c}\text { Kpnl } \\
1\end{array}$} \\
\hline EB02 & (?) & & & & & & & \\
\hline EB01 & $(?)$ & 1 & 2 & 2 & 2 & 3 & 3 & 1 \\
\hline ET02 & $(?)$ & 1 & 2 & 2 & 2 & 3 & 4 & 1 \\
\hline $\mathrm{EBB}^{\mathrm{a}}$ & - & 1 & 2 & 2 & 2 & 1 & 3 & 1 \\
\hline $\mathrm{EBW}^{\mathrm{a}}$ & - & 1 & 2 & 2 & 2 & 3 & 4 & 1 \\
\hline $\operatorname{ManWB}^{\mathrm{a}}$ & - & 1 & 2 & 2 & 2 & 1 & 1 & 1 \\
\hline$c x^{b}$ & (A) & 1 & 1 & 1 & 1 & 1 & 1 & 1 \\
\hline CYE $^{\mathrm{b}}$ & (B) & 1 & 2 & 2 & 2 & 1 & 1 & 1 \\
\hline $\mathrm{PB}^{\mathrm{b}}$ & (C) & 2 & 2 & 2 & 3 & 1 & 2 & 1 \\
\hline $\mathrm{GR} 1^{\mathrm{b}}$ & (D) & 1 & 2 & 2 & 4 & 1 & 2 & 1 \\
\hline $\mathrm{SP} 1^{\mathrm{b}}$ & $(E)$ & 1 & 1 & 1 & 2 & 1 & 3 & 1 \\
\hline$M W 1^{b}$ & $(F)$ & 1 & 2 & 2 & 2 & 1 & 2 & 1 \\
\hline$W W B^{b}$ & $(G)$ & 1 & 1 & 1 & 2 & 2 & 1 & 1 \\
\hline $\mathrm{PoiBl}^{\mathrm{e}}$ & $(\mathrm{H})$ & 1 & 1 & 1 & 2 & 1 & 1 & 1 \\
\hline$V G Y^{c}$ & (I) & 1 & 1 & 1 & 2 & 1 & 1 & 1 \\
\hline $\operatorname{ChWB}^{\mathrm{d}}$ & $(\mathrm{J})$ & 1 & 2 & 2 & 2 & 1 & 2 & 1 \\
\hline
\end{tabular}

Os números representam os diferentes tipos de padrões obtidos para cada enzima de restrição. $C X=$ Canadian X-disease; $C Y E=$ Clover yellow edge; $P B=$ Pecan bunch; $G R 1=$ Goldrod yellows; SP1 = Spirea stunt; MW1 = Milkweed yellows; WWB = Walnut witches'-broom; PoiBI = Poinsetia branch-inducing; VGY = Virginia grapevine yellows; ChWB = Chayote witches'-broom; EBB = Eggplant witches'-broom; EWB = Eggplant big bud e ManWB = Manihots witches'-broom.

$a=$ descritos por Barros (2002); b = descritos por Lee et al (1998); $c=$ descrito por Davis et al. (1998); $d$ = descrito por Montano et al (2000); e = descrito por Davis et al (não publicado, citado por Barros, 2002). 


\subsection{Sequenciamento}

Após o sequenciamento e alinhamento, foi possível identificar polimorfismo nas seqüências nucleotídicas dos fragmentos clonados. Dessa maneira, foram identificadas duas populações nucleotídicas (\#1 e \#2) a partir do isolado da amostra EB01, quatro (\#3, \#4, \#5 e \#6) a partir do isolado da amostra EB02 e três populações (\#7, \#8 e \#9) a partir do isolado da amostra ET02.

Apesar destes polimorfismos, as seqüências dos fragmentos clonados apresentaram índices de identidade de 99\%. O fragmento EB02\#4 apresentou $98 \%$ de identidade quando comparado aos demais fragmentos analisados e 99\% comparado ao EB02\#3. O fragmento EB01\#2 mostrou 98\% de identidade com o fragmento EB02\#3 e EB02\#4, e 99\% com os demais fragmentos sequenciados.

Tabela 2. Posições dos polimorfismos nas seqüências do 16S rDNA do isolado proveniente da amostra EB01

\begin{tabular}{ccc}
\hline & \multicolumn{2}{c}{ EB01 } \\
Posição & \multicolumn{2}{c}{ Fragmentos clonados } \\
\cline { 2 - 3 } 199 & $\# 1$ & $\# 2$ \\
543 & $\mathrm{~T}$ & $\mathrm{C}$ \\
798 & $\mathrm{~A}$ & $\mathrm{G}$ \\
1202 & $\mathrm{~A}$ & $\mathrm{C}$ \\
& $\mathrm{T}$ & $\mathrm{A}$ \\
\hline
\end{tabular}

A comparação das seqüências dos fragmentos \#1 e \#2 obtidas da amostra EB01 revelou a presença de quatro posições onde houveram variação de nucleotídeos.

Na tabela 3, comparando os fragmentos \#7 e \#8, obtidos a partir da amostra ET02, puderam ser observadas quatro posições em que os nucleotídeos se diferenciaram, enquanto que comparando o fragmento \#7 com o \#9, as variações de nucleotídeos ocorrem em apenas duas posições. Quando 
se confrontou o fragmento \#8 com o \#9, os nucleotídeos variaram nas seis posições indicadas.

Tabela 3. Posições dos polimorfismos nas seqüências do 16S rDNA do isolado oriundo da amostra ET02

\begin{tabular}{cccc}
\hline & \multicolumn{3}{c}{ ET02 } \\
Posição & \multicolumn{3}{c}{ Fragmentos clonados } \\
\cline { 2 - 4 } 51 & \#7 & \#8 & $\# 9$ \\
128 & $\mathrm{~T}$ & $\mathrm{C}$ & $\mathrm{T}$ \\
252 & $\mathrm{G}$ & $\mathrm{A}$ & $\mathrm{G}$ \\
708 & $\mathrm{C}$ & $\mathrm{C}$ & $\mathrm{G}$ \\
1140 & $\mathrm{~T}$ & $\mathrm{~T}$ & $\mathrm{~T}$ \\
1202 & $\mathrm{~T}$ & $\mathrm{C}$ & $\mathrm{T}$ \\
\hline
\end{tabular}

Tabela 4. Posições dos polimorfismos nas seqüências do $16 S$ rDNA do isolado proveniente da amostra EB02

\begin{tabular}{|c|c|c|c|c|}
\hline \multirow[t]{2}{*}{ Posição } & \multicolumn{4}{|c|}{$\begin{array}{l}\text { EB02 } \\
\text { Clones }\end{array}$} \\
\hline & \#3 & $\# 4$ & $\# 5$ & \#6 \\
\hline 186 & $\mathrm{~T}$ & C & C & C \\
\hline 256 & C & $\mathrm{T}$ & C & C \\
\hline 342 & $\mathrm{~T}$ & $\mathrm{~T}$ & C & $\mathrm{T}$ \\
\hline 373 & C & $\mathrm{T}$ & C & C \\
\hline 444 & C & C & $\mathrm{T}$ & $\mathrm{T}$ \\
\hline 455 & G & $\mathrm{T}$ & G & G \\
\hline 466 & A & A & G & G \\
\hline 481 & G & A & $G$ & $G$ \\
\hline 491 & G & A & G & G \\
\hline 494 & G & C & $\mathrm{G}$ & G \\
\hline 515 & G & A & $\mathrm{G}$ & G \\
\hline 545 & A & C & A & A \\
\hline 549 & G & A & G & G \\
\hline 674 & C & C & $\mathrm{T}$ & C \\
\hline 787 & G & A & $A$ & A \\
\hline 1018 & C & C & C & $\mathrm{T}$ \\
\hline 1085 & C & C & $\mathrm{T}$ & $\mathrm{T}$ \\
\hline 1097 & C & C & A & A \\
\hline
\end{tabular}


$\mathrm{O}$ isolado proveniente da amostra EB02 (Tabela 4) foi o que apresentou maior número de polimorfismos das seqüências nucleotídicas de seus fragmentos clonados, gerando quatro populações heterogêneas, revelando possivelmente uma maior variação genética nesse isolado. 0 fragmento \#3 comparado ao \#4 mostrou onze posições em que os nucleotídeos variaram, enquanto \#5 e \#6, apenas três variações. $O$ fragmento que mais se diferenciou foi o \#4. Quando comparado ao \#5, exibiu quinze polimorfismos de nucleotídeos em suas seqüências e, em comparação com o fragmento \#6, quatorze variações.

Com base na análise da seqüência 16S rDNA, uma árvore filogenética (Figura 14) foi construída, mostrando a relação entre os fragmentos clonados e seqüências de fitoplasmas, alguns com mais de um operon, pertencentes a subgrupos distintos depositadas no "GenBank" (Tabela 5).

Os resultados obtidos pela árvore filogenética indicam que os isolados encontrados nas amostras EB01, EB02 e ET02 pertencem ao grupo 16Srlll, e que os fragmentos clonados exibem um padrão de subgrupo distinto daqueles disponíveis, relatados na literatura.

O agrupamento de fitoplasmas no mesmo ramo da árvore filogenética sugere um operon ancestral comum a eles. Existe a hipótese provável de que os isolados das amostras EB01, EB02 e ET02 pertençam a um subgrupo distinto dos observados para o grupo $16 \mathrm{Srlll}$, relatados neste trabalho (Jomantiene et al. ,2002).

Schneider \& Seemüller (1994) mostraram que o genoma de fitoplamas contêm duas ou mais populações do gene 16S rDNA. O presente trabalho revelou que os isolados presentes nas amostras EB01, EB02 e ET02 possuem essa heterogeneidade da seqüência 16S rDNA, o que dificulta sua classificação em subgrupos, porém não compromete a identificação do grupo ao qual pertencem, comprovando a eficiência das atuais técnicas de detecção desse fitopatógeno. 
De acordo com Jomantiene et al. (2002), os diversos subgrupos do grupo 16Srlll podem eventualmente ser reconhecidos como linhagens diferentes da mesma espécie, embora este taxon ainda não tenha sido reconhecido para fitoplasmas.

Tabela 5. Fitoplasmas do grupo 16Srlll, números de acesso no "GenBank" e referências usadas nesse trabalho

\begin{tabular}{|c|c|c|c|}
\hline Fitoplasma & Sub-grupo & Acesso & Referência \\
\hline$C X$ & A & L33733 & Gundersen et al., 1994 \\
\hline CYE & B & AF175304 & Davis \& Dally, 2001 \\
\hline SP & $E$ & AF190228 & "GenBank" \\
\hline MW1 & $\mathrm{F}$ & AF510724 & "GenBank" \\
\hline WWB & G & AF190226 & "GenBank" \\
\hline PoiBl & $\mathrm{H}$ & AF190223 & "GenBank" \\
\hline VGY & I & AF060875 & Davis et al. (1998) \\
\hline ChWB & $\mathrm{J}$ & AF147706 & Montano et al. (2000) \\
\hline DVA & $P$ & AF370119 & Jomantiene et al. (2002) \\
\hline DVB & $P$ & AF370120 & Jomantiene et al. (2002) \\
\hline BRWB7 & Q & AF302841 & "GenBank" \\
\hline CWLA & $\mathrm{R}$ & AF373106 & Jomantiene et al. (2002) \\
\hline CWLB & $\mathrm{R}$ & AF373105 & Jomantiene et al. (2002) \\
\hline \multicolumn{4}{|c|}{$\begin{array}{l}\mathrm{CX}=\text { Canadian Peach X-disease; ChWB = Chayote witches'broom; DVA = Dandelion } \\
\text { Virescence (operon A); DVB = Dandelion Virescence (operon B); BRWB7 = Black Raspberry } \\
\text { witches' broom (clone BRWB7); CWLA = Cirsium White Leaf (operon A) e CWLB = Cirsium } \\
\text { White Leaf (operon B); CYE = Clover yellow edge (operon); SP = Spirea stunt (operon A); MW1 } \\
=\text { Milkweed yellows; WWB = Walnut witches'-broom (operon A); PoiBI = Poinsetia branch- } \\
\text { inducing (operon); VGY = Virginia grapevine yellows }\end{array}$} \\
\hline
\end{tabular}




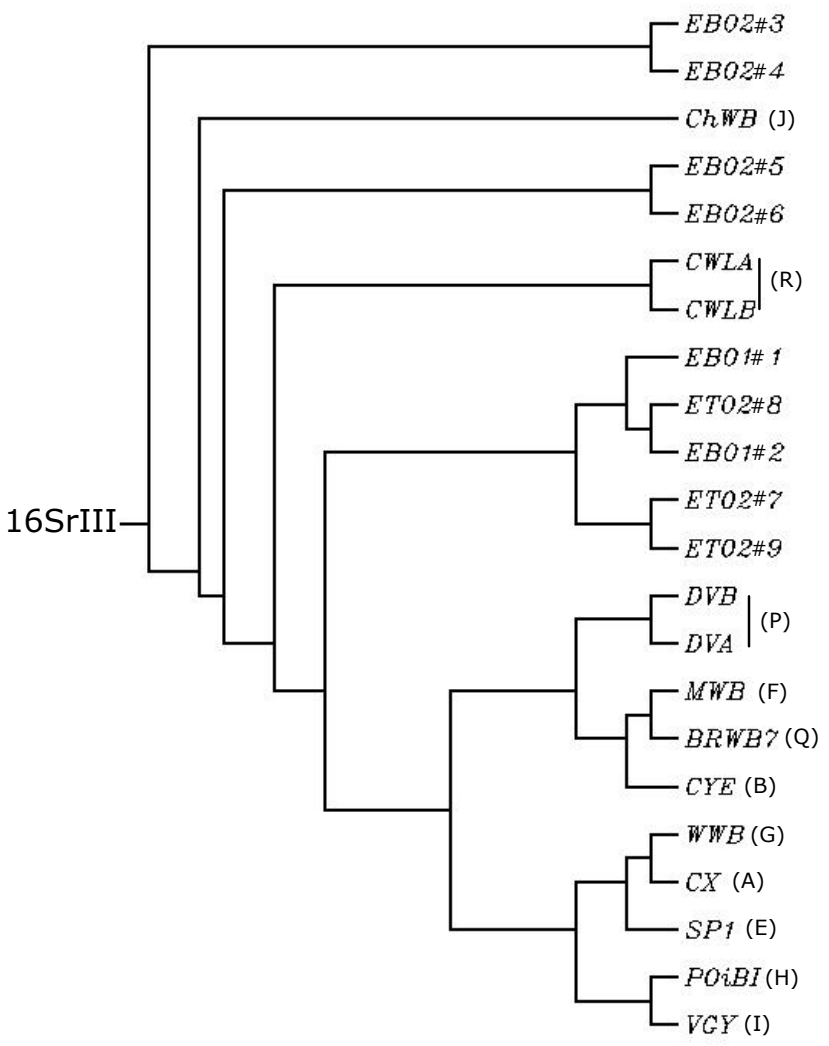

Figura 14 - Árvore filogenética das seqüências do $16 \mathrm{~S}$ rDNA dos fragmentos clonados dos isolados obtidos a partir das amostras EB01, EB02 e ET02 alinhados com fitoplasmas de subgrupos distintos, construída pelo método "Neighbor-Joining", do programa CLUSTALW

Vários outros estudos demonstraram, como neste trabalho, que a análise através de RFLP pode fornecer a primeira indicação da heterogeneidade da seqüência $16 S$ rDNA, em um único fitoplasma. Essas seqüências heterogêneas do genoma do fitoplasma podem diferir uma da outra por não mais do que um nucleotídeo em posições distintas e são filogeneticamente próximas (Davis \& Dally, 2001), como observado na figura 14. 
Os mapas de restrição obtidos a partir do corte das seqüências nucleotídicas heterogêneas, com as mesmas enzimas de restrição usadas para a análise por RFLP, com exceção da Msel, podem ser observados nas Figuras 15 A e B. As seqüências foram comparadas mostrando que a substituição de um nucleotídeo, pode eliminar o local de reconhecimento de uma determinada enzima de restrição, mas isso não ocorre necessariamente uma vez que o nucleotídeo variado pode não fazer parte do sítio de reconhecimento dessa determinada enzima de restrição. Exemplo disso pode ser observado na Figura 15 A. As seqüências nucleotídicas obtidas a partir da amostra EB01 não apresentaram mudanças em seus padrões de corte com as enzimas de restrição.

As seqüências oriundas da amostra EB02 exibem diferenças tanto nos cortes com a enzima Rsal como com os da enzima Hhal, gerados virtualmente. As diferenças podem ser observadas tanto em posições (comparados às seqüências de isolados distintos), quanto em ausências de sítios de restrição nas seqüências nucleotídicas do mesmo isolado (EB02). Na figura $15 \mathrm{~B}$, nota-se ausência de sítio de restrição para a enzima Rsal na seqüência do fragmento \#9, obtida a partir de isolado da amostra ET02. 

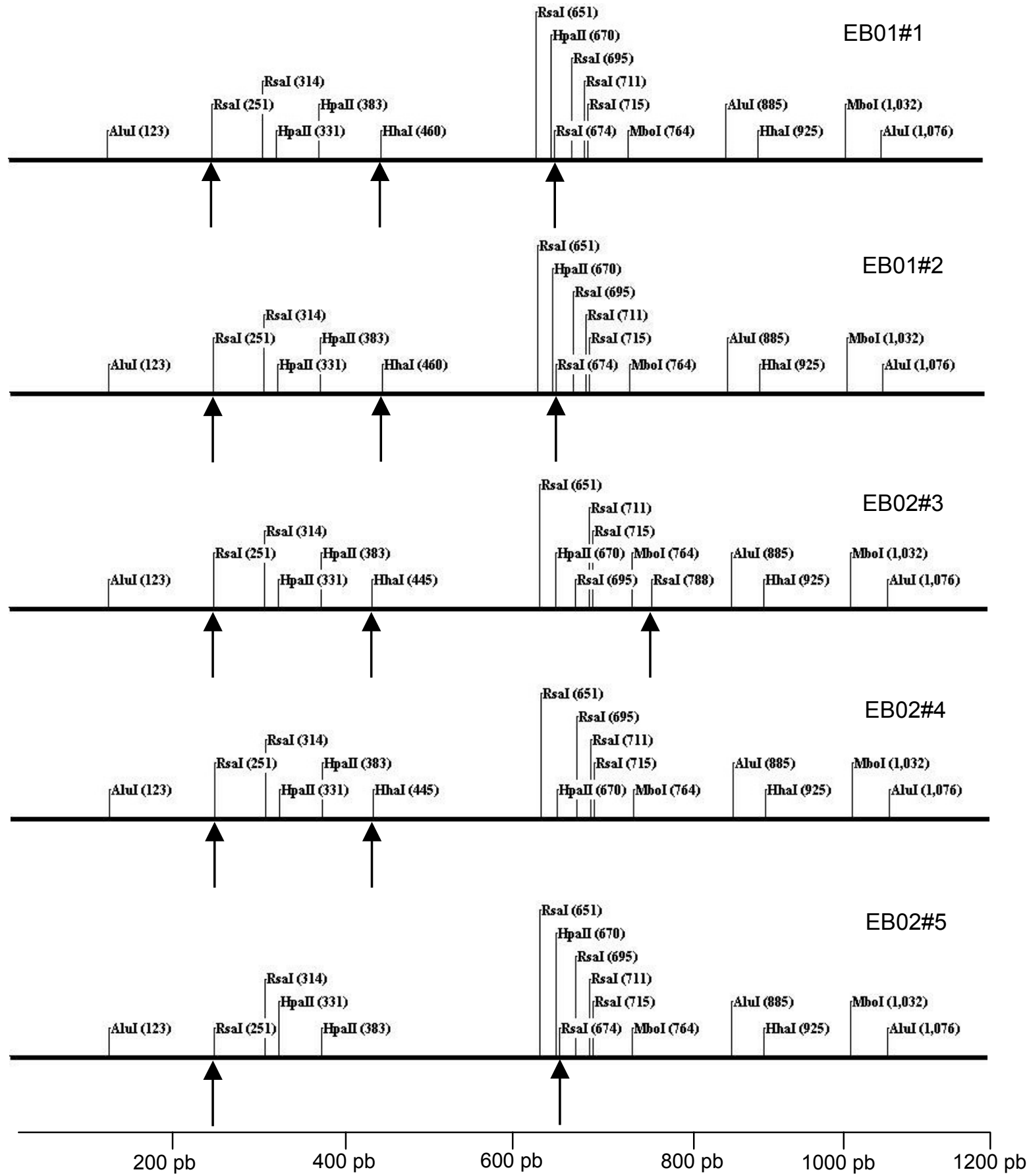

Figura 15 A - Análise dos mapas de restrição gerados a partir das seqüências do 16S rDNA dos fragmentos clonados dos fitoplasmas provenientes das amostras EB01 e EB02. As setas indicam a presença de sítio de restrição distinto em relação às outras 
seqüências. A barra contínua representa o tamanho do fragmento amplificado pelo par de oligonucleotídeo R16 F2n/R2 através de PCR.
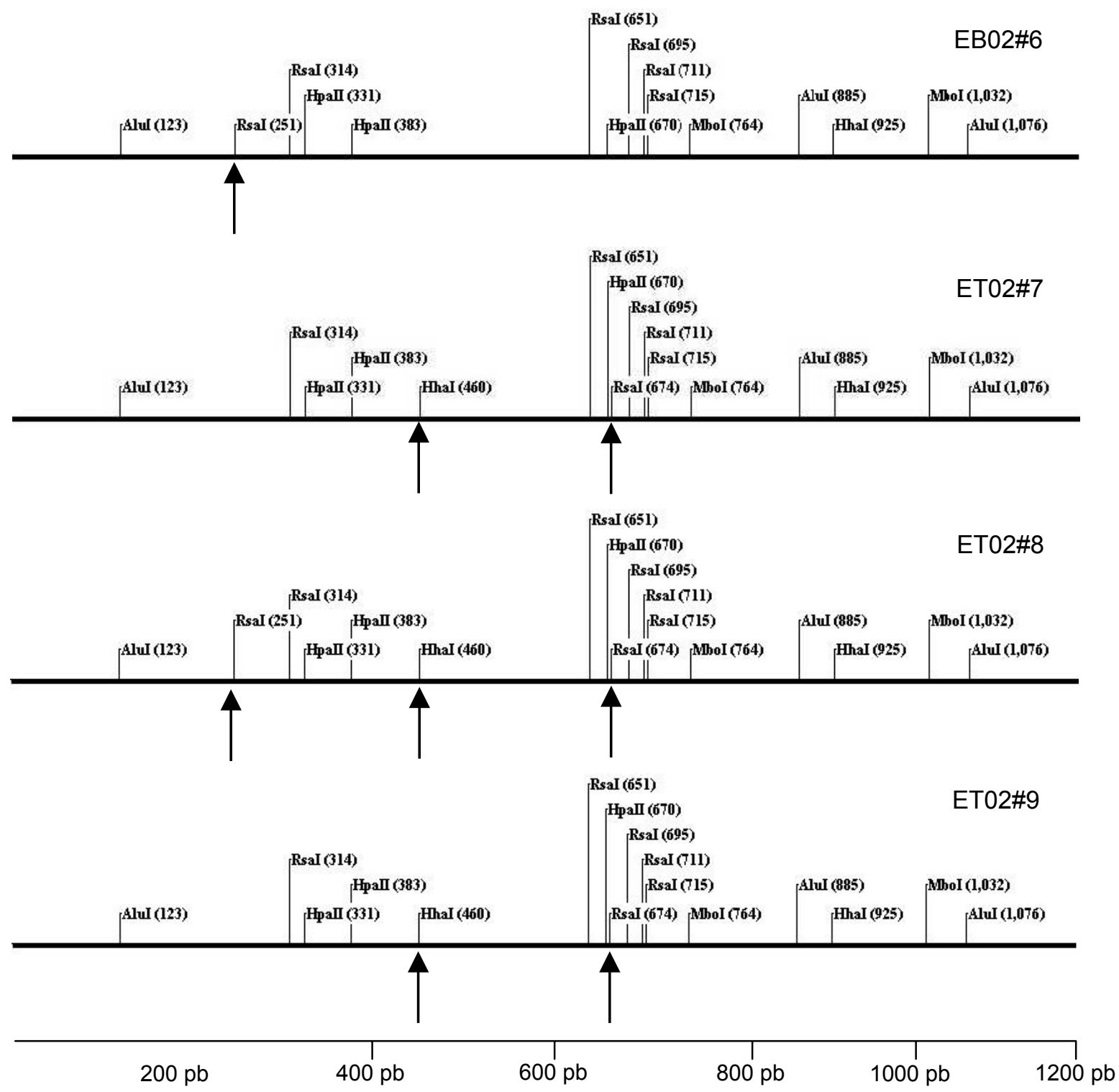

Figura 15 B - Análise dos mapas de restrição gerados a partir das sequências do 16S rDNA dos fragmentos clonados dos fitoplasmas provenientes das amostras EB02 e ET02. As setas indicam a presença de sítio de restrição distinto em relação às outras 
seqüências. A barra contínua representa o tamanho do fragmento amplificado pelo par de oligonucleotídeo R16 F2n/R2 através de PCR.

A observação de seqüências heterogêneas nos isolados encontrados neste estudo, contribui para o conhecimento da diversidade de fitoplasmas do grupo $16 \mathrm{Srlll}$ no Brasil, corroborando com o relato feito por Barros (2002). A presença de mais de um operon ribossomal pode permitir uma maior variabilidade genética. $\mathrm{O}$ organismo que apresenta dois ou mais operons em seu genoma pode sintetizar maior quantidade de proteínas e enzimas, permitindo uma maior competitividade do patógeno. Talvez isso explique uma maior freqüência de ocorrência de fitoplamas afiliados ao grupo $16 \mathrm{Srlll}$.

A causa da heterogeneidade ainda é desconhecida, portanto, estudos futuros devem ser conduzidos no sentido de se determinar a seqüência genômica do fitoplasma. Este tipo de estudo, porém, ainda é dificultado pela impossibilidade de cultivo desse tipo de patógeno em meio de cultura. 


\section{CONCLUSÕES}

Com base nos resultados pode-se concluir que:

1 Fitoplasmas foram detectados nas amostras sintomáticas de berinjela (EB01 e EB02) e de tomate (ET02), com os pares de oligonucleotídeos universais $\mathrm{R} 16 \mathrm{mF} 2 / \mathrm{mR} 1$ e R16 F2n/R2, através da técnica de duplo PCR.

2 Os fitoplasmas detectados em plantas de berinjela e tomateiro foram classificados como representantes do grupo 16Srlll, usando duplo PCR com oligonucleotídeos específicos R16 (III) F2/R1.

3 As análises de RFLP dos produtos de PCR, confirmaram a ocorrência de fitoplasmas afiliados ao grupo $16 \mathrm{Srlll}$ em plantas de berinjela e tomateiro e evidenciaram a heterogeneidade das seqüências do $16 \mathrm{~S}$ rDNA nos isolados.

4 Foram demonstradas, através de sequenciamento do $16 \mathrm{~S}$ rDNA, populações heterogêneas do gene para os isolados provenientes de tomateiro e berinjela. 


\section{REFERÊNCIAS BIBLIOGRÁFICAS}

ALMA, A.; DAVIS, R.E.; VIBIO, M.; DANIELLI, A.; BOSCO, D. ARZONE, A. BERTACCINI, A. Mixed infection of grapevines in northern Italy by phytoplasmas including 16S rRNA RFLP subgroup 16Srl - B strains previosly unreported in this host. Plant Disease, v.80, p.418-421, 1996.

ANFOKA, G.H.A.; KHALIL, A.B.; FATTASH, I. Detection and molecular characterization of a phytoplasma associated with big bud disease of tomatoes in Jordan. Journal of Phytopathology, v.151, n.4, p.223-227, 2003.

BARROS, T.S.L. Fitoplasmas no Brasil: caracterização molecular via "polymerase chain reaction" and "restriction fragment length polymorphism". Brasília, 1997. 89p. Dissertação (M.S.) - Universidade de Brasília.

BARROS, T.S.L. Caracterização molecular de Mollicutes fitopatogênicos no Brasil. Brasília, 2002. 105p. Tese (Doutorado) - Universidade de Brasília.

BOITEUX, L.S.; KITAJIMA. Superbrotamento da berinjela associada a organismos do tipo micoplasma no Distrito Federal. Fitopatologia Brasileira, v.17, n.2, p.196, 1992. 
BOITEUX, L.S.; LIMA, M.I.; KITAJIMA, E.W. Giant calyx: a disease of eggplant (Solanum melongena) associated with a mycoplasma-like organism in Brazil. Plant Pathology, v.43, p.751-754, 1994.

COE, D.M.; ALSTAFF, G.E. Big bud of tomato found in Central California. Plant Disease Reporter, v.31, p.478-479, 1947.

DALE, J.L.; SMITH, L.D. Mycoplasmalike bodies observed in tomato plants with big bud in Arkansas. Plant Disease Reporter, v.59, p.455-458, 1975.

DAVIS, R.E. Fitoplasmas: fitopatógenos procarióticos sem parede celular, habitantes de floema e transmitidos por artrópodos. Revisão Anual de Patologia de Planta, v.3, p.1-27, 1995.

DAVIS, R.E.; DALLY, E.L. Nonfunctional tRNA gene in an unusual example of rRNA interoperon sequence heterogeneity in phytoplasma. Phytopathology, v.91, p.S21, 2001.

DAVIS, R.E.; LEE, I.M. Mycoplasmalike organisms as plant disease agents - a review. ATCC, Quarterly Newsletter, v.11, p.1-11, 1991.

DAVIS, R.E.; JOMANTIENE, R.; DALLY, E.L.; WOLF, T.K. Phytoplasmas associated with grapevine yellows in Virginia belong to group 16Srl, subgroup A (tomato big bud phytoplasma subgroup), and group 16Srlll, new subgroup I. Vitis, v.37, p.131-137, 1998.

DOI, Y.; TERANAKA, M.; YORA, K.; ASUYAMA, H. Mycoplasma or PLT-grouplike microorganisms found in the phloem elements of plants infected with mulberry dwarf, potato wiches' broom, aster yellows, paulownia wiches broom. Phytopathological Society of Japan., v.33, p.259-266, 1967. 
FIRRAO, G.; GOBBI, E.; LOCCl, R. Rapid diagnosis of apple proliferation mycoplasma-like organism using polymerase chain reaction procedure. Plant Pathology., v.43, p.669-674, 1994.

FNP CONSULTORIA \& COMÉRCIO. AGRIANUAL 2000: anuário da Agricultura Brasileira. São Paulo, 2000. p.49: Hortaliças: fonte de sabor e saúde.

GOODWIN, P.H.; MAHUKU, G.S.; LIU, H.W; XUE BG. Monitoring phytoplasma in populations of aster leafhopper from lettuce fields using the polymerase chain reaction. Crop Protection, v.18, n.2 p.91-99, 1999.

GRANETT, A.L.; PROVVIDENTI, R. Tomato big bud in New York State. Plant Disease Reporter, v.58, p.211-214, 1974.

GREEN, M.J.; THOMPSON, D.A.; MACKENZIE, D.J. Easy and efficient DNA extraction from woody plants for the detection of phytoplasmas by polymerase chain reaction. Plant Disease, v.83, n.5, p.482-485, 1999.

GUNDERSEN, D.E.; LEE, I.-M. Ultrasensitive detection of phytoplasmas by nested-PCR assays using two universal primer pairs. Phytopathology Mediterranea., v.35, p.144-151, 1996.

GUNDERSEN, D.E.; LEE, I.-M.; REHNER, S.A.; DAVIS, R.E.; KINGBURY, D.T. Phylogeny of mycoplasmalike organisms (Phytoplasma): a basis for their classification. Journal of Bacteriology., v.176, p.5244-5254, 1994.

HANAHAN, D. Studies on transformation of Escherichia coli with plasmids. Journal of Molecular Biology, v.166, n.4, p.557-580, 1983. 
HARRISON, N.A.; RICHARDSON, P.A . TSAI, J.H. EBBERT, M.A. KRAMER, J.B. PCR assay for detection of the phytoplasma associated with maize bushy stunt disease. Plant Disease, v.80, p.263-269, 1996.

HENSON, J.M.; FRENCH, R. The polimerase chain reaction and plant diseases diagnosis. Annual Review of Phytopathology, v.31, p.81-109, 1993.

HOY, C.W.; HEADY, S.E.; KOCH, T.A. Species composition, phenology, and possible origins of leafhopper (Cicadellidae) in Ohio vegetable crops. Journal of Economic Entomology., v.85, p.2336-2343, 1992.

JOMANTIENE, R.; DAVIS, R.E.; VALUINAS, D.; ALMINAITE, A. New group 16Srlll phytoplasma lineages in Lithuania exhibit rRNA interoperon sequence heterogeneity. European Journal of Plant Pathology, v.108, p.507-517, 2002.

KHADHAIR, A.H.; EVANS, I.R.;CHOBAN, B. Identification of aster yellows phytoplasma in garlic and green onio by PCR-based methods. Microbiological Research, v.157, p.1-7, 2002.

KHAN, A.J.; BOTTI, S.; AL-SUBHI, A. M.; GUNDERSEN-RINDAL, D.E. BERTACCINI, A.F. Molecular identification of a new phytoplasma associated with alfafa witches'broom in Oman. Phytopathology, v.92, p.1038-1047, 2002.

KIRKPATRICK, B.C. Mycoplasma-like organisms - Plant and invertebrate pathogens. In: BALLOWS, A.; TRUPER, H.; DWORKIN, M.; HARDER, W.; SCHLEIFER, K. (Ed.). The prokaryotes. New York: Springer, 1992. p.40504067. 
KIRKPATRICK, B.C.; FRASER, J.D. Cloning and parcial sequence of $16 S$ ribossomal RNA gene from the western $x$-disease mycoplasma-like organism. Phytopathology, v.78, p.1541, 1988.

KITAJIMA, E.W. Enfermidade de plantas associadas a organismos do tipo micoplasma. Revisão Anual de Patologia de Plantas, v.2, p.153-174, 1994.

KITAJIMA, E.W.; COSTA, A. S. Estruturas do tipo micoplasma no floema de tomateiro afetado pelo cálice gigante. Bragantia, v.27, n.2, p.97-99, 1968.

KITAJIMA, E.W.; COSTA, A. S. Micoplasma: Possível agente etiológico de certas moléstias de plantas. Ciência e Cultura, v.22, n.4, p.351-363, 1970.

KITAJIMA, E.W.; NOME, C.F. Microscopia electronica en virologia vegetal. In: DOCAMPO, D.M.; LENARDÓN, S.L. Métodos para detectar patógenos sistémicos. Córdoba: IFFIVE; NTA; JICA, 1999. p.59-86.

LEE, I.M; DAVIS, R.E.; GUNDERSEN-RINDAL, D.E. Phytoplasma: Phytopathogenic mollicutes. Annual Review of Microbiology, v.54, p.221-255, 2000.

LEE, I.M.; BERTACCINI, A.; VIBIO, M.; GUNDERSEN, D.E. Detection of multiple phytoplasmas in perennial fruit trees with symptoms in Italy. Phytopathology, v.85, p.728-735, 1995.

LEE, I.M; HAMMOND, R.W; DAVIS, R.E. Universal amplification and analysis of pathogen 16S rDNA for classification and identification of mycoplasmalike organisms. Phytopathology, v.83, p.834-842, 1993. 
LEE, I.M.; GUNDERSEN-RINDAL, D.E.; DAVIS, R.E., BARTOSZIK, I.M. Revised classification scheme of phytoplasma based on RFLP analyses of 16S rDNA and ribosomal protein tgene sequences. International Journal of Systematic Bacteriology, v.48, p.1153-1169, 1998.

LEE, I.M.; GUNDERSEN-RINDAL, D.E.; HAMMOND, R.W; DAVIS, R.E. Use of mycoplasmalike organism (MLO) group-specific oligonucleotide primers for nested PCR assay to detect mixed MLO infections in a single host plant. Phytopathology, v.84, p.559-566, 1994.

LIM, P.-O; SEARS, B.B. 16S rRNA sequence indicates that plant pathogenic mycoplasmalike organisms are evolutionary distinct from animal mycoplasma. Journal of Bacteriology, v.171, p.5901-5906, 1989.

MARCONE, C.; RAGOZZINO, A; SEEMULLER, E. Detection of anelm yellowrelated phytoplasmas in eucalyptus trees affected by little-leaf disease in Italy. Plant Disease, v.80, p.669-673, 1996.

MARCONE, C.; LEE, I.M.; DAVIS, R.E.; RAGOZZINO, A; SEEMULLER, E. Classification of aster yellows-groups phytoplasmas based on combined analysis of rRNA and tuf genes sequences. International Journal of Systematic Evolutionary Microbiology, v.50, p.1703-1713, 2000.

MARTIN, R.R; JAMES, D.; LÉVESQUE, C. A. Impacts of molecular diagnostic technologies on plant disease management. Annual Review of Phytopathology, v.38, p.207-239, 2000.

MONTANO, H.G.; DAVIS, R.E.; DALLY, E.L.; PIMENTEL, J.P.; BRIOSO, P.S.T. Identificatio and phylogenetic analyses of a new phytoplasma from disease chayote in Brazil. Plant Disease, v.84, p.429-436, 2000. 
MONTANO, H.G.; DAVIS, R.E.; DALLY, E.L.; HOGENHOUT, S.; PIMENTEL, J.P.; BRIOSO, P.S.T. 'Candidatus phytoplasma brasiliense', a new phytoplasma taxon associated with hibiscus witches'broom disease. International Journal of Systematic and Evolutionary Microbiology, v.51, p.1109-1118, 2001.

MURRAL, D.J.; NAULT, L.R.; HOY, C.W.; MADDEN, L.V.; MILLER, S.A. Effects of temperature and vector age on transmission of two Ohio strains of aster yellows phytoplasma by the aster leafhopper. Journal of Economic Entomology, v.89, n.5, p.1223-1232, 1996.

SALEHI, M.; IZADPANAH, K.; TAGHIZADEH, M. Herbaceous host range of lime witches' broom phytoplasma in Iran. Iranian Journal of Plant Pathology, v.36, n.3-4, p.101-102, 2000.

SAMBROOK, J.; FRITSCH, E.F.; MANIATIS, T. Molecular cloning: A laboratory manual. 2.ed. Cold Spring Harbor, New York: Cold Spring Harbor Laboratory Press, 1989.

SAMUEL, G.; BALD, J.G.; EARDLEY, C.M. "Big bud", a virus disease of the tomato. Phytopathology, v.23, p.641-653, 1933.

SCHAFF, D.; LEE, I.M.; DAVIS, R.E. Sensitive detection and identification of mycoplasmalike organisms by polymerase chain reaction. Biochemical Biophysical Research Communication, v.186, p.1502-1509, 1992.

SCHNEIDER, B ; SEEMÜLLER, E. Presence of two sets ribossomal genes in phytopathogenic mollicutes. Applied and Environmental Microbiology, v.60, p.3409-3412, 1994. 
SEARS, B.B.; KIRKPATRICK, B.C. Uveiling the evolutionary relationship of plant-pathogenic mycoplasma-like organisms. ASM News, v.60, p.307-312, 1994.

SERRONE, Pd.; MERZACHI, C.; BRAGALONI, M.; GALEFFI, P. Phytoplasma infection of tomato in central Italy. Phytopathology Mediterranea, v.40, p.137-142, 2001.

SHAW, M.E.; KIRKPATRICK, B.C. The beet leafhopper- transmitted virescence agent causes tomato big bud disease in California. Plant Disease, v.77, n.3, p.290-295, 1993.

SIDDIQUE, A .B.M.; AGRAWAL, G.K.; ALAM, N.; KRISHNA REDDY, M. Electron microscopy and molecular characterization of phytoplasmas associated with little leaf disease of brinjal (Solanum melongena L.) and periwinkle (Catharanthus roseus) in Bangladesh. Journal of Phytopathology, v.149, p.237-244, 2001.

VALENTA, V.; MUSIL, M.; MISIGA, S. Investigations on European yellows-type viruses. The stolbur virus. Phytopathology, v.42, p.1-38, 1961.

VARMA, J.P. Occurrence of tomato big bud like disease in Haryana. Science and Culture, v.45, p.205-207, 1979.

ZIMMERMAM-GRIES, S.; KLEIN, M. A tomato big bud-like disease of tomatoes in Israel and its association with mycoplasmalike organisms. Plant Disease. Reporter, v.62, p.590-594, 1978. 